\title{
A ESTÉtICA DA REVOLUÇÃo DE OUTUBRO: RETOMAdA DO POTENCIAL EMANCIPATÓRIO RADICAL ${ }^{1}$ \\ AESTHETICS OF THE OCTOBER REVOLUTION: RESUMPTION OF THE RADICAL EMANCIPATORY POTENTIAL
}

Martonio Mont'Alverne Barreto Lima² Vinícius Madureira Maia ${ }^{3}$

\begin{abstract}
Resumo: A partir de uma metodologia de breve recensão de filmes circunscritos ou não ao circuito hollywoodiano, com o presente artigo teve-se por intento uma análise do processo cinematográfico de redução ideológica de um evento histórico tido por traumático (no caso, a Revolução Russa) a mero epifenômeno de uma narrativa familiar-conjugal, a fim de que o seu significado simbólico seja melhor apropriado no âmbito dos atuais consensos do Estado espetacular integrado e do capital-parlamentarismo. Tendo como marco referencial teórico a filosofia marxista de Slavoj Žižek e, em menor grau, de Alain Badiou, não desacompanhada do relato histórico de cronistas clássicos e demais scholars no tocante à Revolução de 1917 e seus desdobramentos, propõe-se a retomada - conceito caro a Kierkegaard - do intrínseco potencial emancipatório radical do "Evento-Lênin" e da "Ideia de Comunismo", subjacentes àquele procedimento redutivo-apropriativo, como tarefa da historiografia crítica contemporânea.
\end{abstract}

Palavras-chave: Revolução Russa. Utopia. Marxismo. Revolução. Retomada.

\begin{abstract}
Based on a methodology of a brief movies' review, which may be or may not be circumscribed to the Hollywood circuit, the present work aimed at presenting an analysis of the cinematographic process of ideological reduction of a historical event considered traumatic (in this case, the Russian Revolution) to a regular family-conjugal narrative's epiphenomenon. In such a way that its symbolic meaning can be better appropriated within the framework of the current consensus of the integrated spectacular power and of the capital-parliamentarism. Having as theoretical background the philosophy of Slavoj Žižek and, to a lesser extent, of Alain Badiou, both contemporary Marxists, not without the report of several classical historians and subject matter experts regarding the Revolution of 1917, it is proposed the resumption - a dear concept to Kierkegaard - of the intrinsic radical emancipatory potential of the "Event of Lenin" and of the "Idea of Communism", which underlie that reductive-appropriative procedure, as a major task of the contemporary critical historiography.
\end{abstract}

Keywords: Russian Revolution. Utopia. Marxism. Revolution. Resumption.

\footnotetext{
1 Artigo dedicado ao cinquentenário de La Société du Spetacle, ao centenário da Revolução Russa e ao sesquicentenário de $O$ Capital.

2 Pós-Doutor e Doutor em Direito pela Universidade de Frankfurt, Alemanha; Professor Titular da Universidade de Fortaleza; Avenida Washington Soares, 1321, Edson Queiroz, 60811-905, Fortaleza, Ceará, Brasil; barreto@unifor.br; https://orcid. org/0000-0003-0052-2901

3 Graduado em Direito pela Universidade de Fortaleza; mestrando em Sociologia pela Universidade Estadual do Ceará; vi.madureira@gmail.com; https://orcid.org/0000-0001-5301-0155
} 


\section{Introdução}

Certa feita, em 1972, durante visita de Richard Nixon a Beijing, ao ser indagado acerca do significado da Revolução Francesa, o então Primeiro Ministro da República Popular da China, Zhou Enlai - homem de confiança de Mao Tsé-Tung -, redarguiu de forma breve e lapidar: "É ainda cedo demais para falar." ${ }^{4}$

Embora essa sua célebre reposta possa ser tomada apressadamente como um exemplo da sabedoria e longanimidade orientais, bastante repisadas cá no Ocidente, é possível que Zhou Enlai tenha se equivocado quanto à pergunta (em virtude da tradução simultânea): o assunto referir-se-ia, antes, aos eventos políticos de maio de 1968, quase coevos à época. Contudo, o diplomata americano Chas Freeman, presente na ocasião, teria dito mais tarde que o erro era, de qualquer modo, "delicioso demais para atrair correção."

Em que pese ao influxo dessa evasiva um tanto sibilina, se é mesmo algo precipitado debruçarse atualmente sobre a noção e o legado de uma revolução bissecular, o que dizer, então, da Revolução de 1917, seu recém-completo primeiro centenário? Que representariam hoje seus símbolos, seus maiores expoentes? Não surpreende que ao se perguntar quais seriam, em longo prazo, as prováveis influências da Revolução Russa, ${ }^{6}$ o historiador britânico Christopher Hill (1967, p. 178) tergiversasse bem antes do próprio Zhou Enlai: "É ainda muito cedo para ensaiar qualquer resposta."

Idealizar convulsões sociais provenientes de terras estrangeiras é uma tentação a que cede com razoável facilidade certa gente jovem ou de índole política mais ou menos sugestiva, com alguma predisposição à militância, ao alistamento. É com essa contrição de sentimento que Edmund Wilson inaugura, em 1971, sua reavaliação do "retrato excessivamente lisonjeiro" - segundo a crítica geral a qual se seguiu à publicação do seu hoje clássico Rumo à Estação Finlândia - que fizera dos eventos em torno da Revolução de Outubro, bem como da personalidade e atos de Lênin em comparação a Stalin. Ao presumir, em 1940, que uma "reviravolta fundamental" teve lugar na Rússia, que um passo importante na história da humanidade foi então dado em 1917, "nada me levava a desconfiar", justifica-se o historiador, "que a União Soviética viria a tornar-se uma das mais abomináveis tiranias que o mundo jamais conhecera." (WILSON, 2006, p. 548). Aqui se previne o leitor, pois, de uma leitura do presente texto com um viés incorretamente hagiológico. Não é essa a intenção dos autores, é bem que se diga, de fazer dele uma espécie de prosélito. Nada mais errôneo.

\footnotetext{
4 Como sucede a qualquer história com ares de anedota, esta admite igualmente as variações de praxe. Žižek também costuma contar o episódio, mas situando-o em 1953, quando de uma aparente visita de Zhou Enlai a Genebra, a fim de participar das negociações de paz com vistas ao fim da guerra na Coreia; um jornalista francês, e não o presidente Nixon em pessoa, teria feito a pergunta que deu ensejo à sua fatídica resposta (cf. Žižek, 2008b, p. 30, 2011, p. 167-168).

5 No original: "At a seminar in Washington to mark the publication of Henry Kissinger's book, On China, Chass Freeman, a retired foreign service officer, sought to correct the long-standing error. "I distinctly remember the exchange. There was a misunderstanding that was too delicious to invite correction." Vide, a propósito, a matéria Zhous cryptic caution lost in translation, publicada na edição do Financial Times de 10 de junho de 2011. Disponível em: <https://goo.gl/kqtZSu >. Acesso em: 05 maio 2017.

6 No mesmo sentido: "Surprisingly, given its importance, the October Revolution has remained one of the least examined and most poorly understood aspects of 1917." (WHITE, 2004, p. 187).
} 
Em todo caso, uma discorrência que se queira íntegra acerca das reverberações de Outubro na contemporaneidade não pode logicamente prescindir do espólio leninista, sem o qual é impossível uma captura do todo revolucionário russo do início do último século. Tomar parte, contudo, no inventário conceitual de Lênin, proceder ao levantamento detalhado do "implacável enfoque na luta de classes; o partido como forma privilegiada de organização; a tomada violenta e revolucionária do poder; a consequente "ditadura do proletariado" (cf. ŽIŽEK, 2005a, p. 7), é um assunto hoje delicado em demasia para sequer ser tratado com o pretenso equilíbrio, como tópico legítimo de debate, mesmo após a dissolução da URSS e a consagração do consenso democrático-liberal vigente, em que a liberdade, não apenas de expressão, mas em todas as suas vertentes constitucionais, são apregoadas a mais não poder - nada obstante à observação acrimoniosa feita por Marx "em $O$ Manifesto Comunista, de que a liberdade burguesa é a liberdade de comerciar, comprar e vender" (ŽIŽEK, 2012b, p. 299, grifo do autor). É permitido, claro, ocupar-se academicamente de Lênin e da Revolução Russa, contanto que com eles se detenha de modo "crítico" e "científico" apenas, a não ser que se pretenda relegar, nas palavras decerto irônicas do filósofo esloveno, a "objetividade científica em troca de posturas ideológicas ultrapassadas (ŽIŽEK, 2005a, p. 174). ${ }^{7}$

É que algo de tanatopraxia parece estar implicado nesse tratamento intelectual, daí a misologia geral quanto ao legado do maior "defunto" soviético: com a derrocada do comunismo, Lênin não se mostrou só mais um descendente da pouco prestigiosa linhagem intelectual europeia do "cachorro morto" [der tote Hund], que remonta genealogicamente a Marx, Hegel, Lessing, Mendelssohn e Spinoza? (cf. LIESMANN, 2012, p. 9-12). Não é fácil de se encontrar, em certos haras acadêmicos, ${ }^{8}$ a hombridade ulterior de um Karl Marx - cujos comentários desrespeitosos, dirigidos no decorrer de sua vida a um sem-número de amigos e desafetos, são largamente suscitados e repercutidos por seus adversários ${ }^{9}$ - que, ao se dar conta do costume com que se compraziam,

\footnotetext{
7 Fairclough (2003, p. 14-15), que há muito se dedica à análise crítica do discurso (ADC), bem como a uma assim chamada "filosofia das ciência sociais", advoga que o imperativo da objetividade em tais pesquisas seria uma perspectiva científica a ser superada, dada a sua suposta impraticabilidade: "The general point is that there are always particular motivations for choosing to ask certain questions about texts and not others. My actual motivation for asking the sorts of questions I shall ask in this book is the belief that texts have social, political, cognitive, moral and material consequences and effects, and that it is vital to understand these consequences and effects if we are to raise moral and political questions about contemporary societies, and about the transformations of 'new capitalism' in particular. Some readers may be concerned about the 'objectivity' of an approach to text analysis based upon these motivations. I don't see this as a problem. There is no such thing as an 'objective' analysis of a text, if by that we mean an analysis which simply describes what is 'there' in the text without being 'biased' by the 'subjectivity' of the analyst. As I have already indicated, our ability to know what is 'there' is inevitability limited and partial. And the questions we ask necessarily arise from particular motivations which go beyond what is 'there'." O argumento circunscrito nessa passagem semelha a concepção científica weberiana acerca da objetividade nas ciências sociais, suspeitosa de que todo conhecimento insinuaria uma Wertbeziehung, isto é, uma "relação com os valores" do sujeito cognoscente; a metodologia de apreensão de determinada realidade por parte desse sujeito mal disfarçaria uma seletividade teórica de afinidades próprias [die Wahlverwandtschaften].

8 No que tange a um filoneísmo intelectual de "gosto duvidoso", quase sempre acompanhado de um conhecimento sofrível dos clássicos, certo viajante francês veio a etnografar, algo após sua missão e estada nos trópicos, esse apetite nacional pela novidade: "Produtos selecionados dos haras acadêmicos, meus colegas e eu nos sentíamos às vêzes embaraçados: criados no respeito exclusivo das idéias amadurecidas, éramos alvo dos assaltos de estudantes duma ignorância total com relação ao passado, mas cuja informação estava sempre alguns meses adiante da nossa. Contudo, a erudição, de que não tinham nem o gôsto, nem o método, lhes parecia, apesar de tudo, um dever." (LÉVI-STRAUSS,1957, p. 105, grifo do autor).

9 Edmund Wilson noticia que Engels deu muito de si, a certa altura de sua vida, por imitar as "estimativas desdenhosas" típicas da língua e da pena de Marx: todo mundo no movimento revolucionário, quer fosse um oponente ou mesmo um ca-
} 
nos meios cultos da Alemanha da década de 1860, em tratar Hegel como um "cachorro morto", confessou-se declaradamente discípulo desse "grande pensador", pois reconhecia o velho seminarista de Tübingen como "o primeiro a apresentar as formas gerais do movimento, de maneira ampla e consciente" (MARX, 1969, p. 27), ${ }^{10}$ a despeito de empreender um embate, já à época trintenial, contra a dialética hegeliana no que ela tinha de "mistificação".

Considerando a rarefeita influência política atual de Lênin em meio à intelectualidade dita engajada, não se duvide que também a esquerda teve nisso participação crucial (CALLINICOS, 2007, p. 18). O desaparecimento de Lênin, "um nome perfeitamente impronunciável", na opinião do filósofo francês Jean Salem, entende-se como uma exitosa campanha ideológico-midiática perpetrada sistematicamente por pensadores, intelectuais e jornalistas através do último século, gente do jaez de Alain Besançon, Hannah Arendt, Charles Bettelheim, André Glucksmann, Alexandr Solzhenitsyn, Ernst Nolte, François Furet, Raymond Aron, David Remnick, entre tantos outros empenhados em comprovar uma presumida equiparação do comunismo com o nazismo (SALEM, 2010, p. 5-13), ${ }^{11}$ do Gulag com Auschwitz, a partir do paradigma do "totalitarismo", cuja errônea aplicação, ${ }^{12}$ o mais das vezes sem qualquer percepção de limites, é um exemplo de "falácia de ambiguidade" que se deve, por todos os meios, evitar a nível lógico-discursivo (COPI, 1978, p. 91 e ss.). ${ }^{13}$

Seria o Gulag, de fato, o telos último da Revolução Russa? Tal pergunta, refinadamente retórica - e que é o mote mesmo de October, livro recém-publicado do intelectual britânico China Miéville (2017, p. 350) - tem como pano de fundo um século de discussões bizantinas e, pior, de "ataques cruéis, anistóricos, ignorantes, feitos de má-fé e oportunistamente contra Outubro." Vez que a tentativa de revolução, enquanto fenômeno fundamental de instabilidade, tem por pressupostos a imprevisibilidade, a não linearidade e, porventura, a própria inevitabilidade - esta

marada, era, aos olhos de ambos, um "'Hund', a 'Wanz', a 'Tölpel', a 'Rüpel', a 'Hanswurst', a 'Schafskopf', a 'Schlingel' or a 'Vieh', and as the years go on, the word Esel seems almost to become synonymous with human being." (WILSON, 2003, p. 173).

10 No original: "[...] da】 er ihre allgemeinen Bewegunsformen zuerst in umfassender und bewu $\square$ uter Weise dargestellt hat."

11 A fim de ilustrar a dessemelhança entre ambos, Žižek (2005a, p. 340) reflete sobre uma observação então recente do crítico britânico John Berger "a respeito de um cartaz francês da companhia de investimentos via Internet Selftrade: sob a imagem de uma foice e de um martelo feitos de ouro maciço e cravejados de diamantes, o texto diz: 'E se todo mundo lucrasse com o mercado de ações?'." A estratégia do cartaz é óbvia: atualmente, o mercado de capitais obedece a critérios igualitários comunistas: todos podem participar dele. Berger se permite um exercício intelectual simples: "Imagine uma campanha publicitária hoje que empregasse uma cruz suástica de ouro maciço e cravejada de diamantes! É claro que não daria certo. Por quêe? A suástica se dirigia aos vitoriosos em potencial, não aos derrotados. Invocava dominação e não justiça. A foice e o martelo, pelo contrário, evocavam a esperança de que "a história um dia estaria do lado daqueles que lutam pela justiça fraterna." Portanto, a ironia é que, no próprio momento em que essa esperança é oficialmente dada como morta pela ideologia hegemônica do "fim das ideologias", uma "empresa pós-industrial" paradigmática (existe algo mais "pós-industrial que negociar ações pela Internet?) é obrigada a mobilizar essa esperança latente para poder passar sua mensagem." Vide, a propósito, estudos de história comparada nas respectivas obras editadas por Kershaw e Moshe Lewin (1997) e Rousso (2004).

12 Em 1944 mesmo, George Orwell (2017, p. 88-89) já registrava sarcasticamente a aplicação desbragada da palavra "fascismo", então "quase desprovida de todo significado", porquanto dirigida a conservadores, socialistas, anarquistas, trotskistas, nacionalistas, católicos, e também "a agricultores, a lojistas, ao Crédito Social, ao castigo corporal, à caça à raposa, às touradas, ao Comitê de 1922, ao Comitê de 1941, a Kipling, Gandhi, Chiang Kai-Shek, à homossexualidade, aos programas de rádio de Priestley, aos Albergues da Juventude, à astrologia, às mulheres, aos cães e a não sei o que mais." O mesmo Orwell advertia, de antemão, contra qualquer aproximação aligeirada nesse sentido, pois "mesmo os grandes Estados fascistas diferem em boa medida um do outro em estrutura e em ideologia." (ORWELL, 2017, p. 85).

13 A propósito, recorrente na obra do epistemólogo britânico Roy Baskhar (2008, p. 30) é o sintagma "falácia epistêmica", por meio do qual se dissimularia na tradição realista empírica, uma ontologia baseada na categoria de experiência, e um realismo fundado em características presumidas dos objetos da experiência. 
última de acordo com o marxismo clássico, ou seja, teleologicamente orientada no decurso natural da história - ${ }^{14}$ a ulterior degradação soviética em expurgos e campos de trabalho correcional e colônias não seria simplesmente um resultado cabal, "não estava escrita nas estrelas" (cf. MIÉVILLE, 2017, p. $350),{ }^{15}$ em que pese à insistência de seus oponentes, liberais ou não, em sentido contrário. ${ }^{16}$ Queria-se talvez, de modo deliberado ou mesmo inconsciente, irmanar, por meio desse estratagema, o espírito revolucionário com a má consciência, escamoteá-lo de uma vez por todas da história? Não por acaso o velho Karl se queixava a seu dileto confidente Ludwig Kugelmann, em carta de 03 de março de 1869, que o conservadorismo logrou erradicar da memória coletiva popular suas recordações da então recente Märzrevolution - as Revoluções Alemãs de 1848 (MARX, 1965, p. 596). ${ }^{17}$

Há, porém, uma operação ideológica ainda mais excludente que a própria postura nefanda, silente ou abertamente avessa a determinada figura ou evento históricos, eis que indissociáveis de seu embaraçoso significado simbólico para o atual consenso do Estado espetacular integrado (Debord) ou do capital-parlamentarismo (Badiou): a sua apropriação "edulcorante", por assim dizer, pela ideologia hegemônica (cf. AGAMBEN, 2015, p. 101-102). No seio desta, a Praça Vermelha evocaria, por exemplo, tão somente a candura de um cenário romântico ideal, descrito naquela singela música de Gilbert Bécaud, na qual Lênin, embora já vertido em seu Mausoléu, agiria ainda feito um mediador evanescente [verschwindende Vermittler, no sentido que Frederic Jameson lhe empresta] ${ }^{18}$ entre amores platônicos, juvenis, que torcem para sobreviver ao inverno russo. É significativo que o eu-lírico da canção Nathalie (1964), ao ouvir "frases sóbrias" sobre a "gloriosa" Revolução de Outubro, deseje apenas se desafogar dessa cantilena comunista num copo de chocolate quente do famoso Café Pouchkine, ao lado da pessoa amada...

\author{
$[\ldots]$ \\ La place Rouge était blanche \\ La neige faisait un tapis \\ Et je suivais par ce froid dimanche \\ Nathalie
}

\footnotetext{
$\overline{14}$ Herdeiras da tradição utópica, revoluções seriam uma nova "possibilidade de possibilidades", cada vez mais factíveis nessa contemporaneidade potencial ou imanentemente distópica (MARCUSE, 1980 [1967], p. 9-42). Aliás, a consciência quanto à exequibilidade do programa leninista derivava, segundo um conhecido filósofo húngaro, do sentimento político de "eliminação cabal de todo utopismo" em descompasso com a Realpolitik soviética, ou seja, de contrariedade a qualquer associação do projeto revolucionário a uma empreitada suspicazmente fantasiosa (LUKÁCS, 2009, p. 72). (No original: "the final elimination of all utopianism.").

15 No original: "[...] a hundred years of crude, ahistorical, ignorant, bad-faith and opportunistic attacks on October [...] not a given, was not written in any stars."

16 "[Lenin] stood on the eve of the moment when for the first time in the human exploit the key of a philosophy of history was to fit an historical lock. If the door that Lenin was to open did not give quite on the prospect he hoped, [...] We must not wonder if later events are not always amenable to this pattern. The point is that western man at this moment can be seen to have made some definite progress in mastering the greeds and the fears, the bewilderments, in which he has lived." (WILSON, 2003, p. 467-468).

17 "O esquecimento total da causalidade revolucionária e contra-revolucionária é consequência necessária de qualquer reação vitoriosa." (cf. carta destinada a Marx, escrita em Manchester, em 18 de dezembro de 1868, por ENGELS apud BENJAMIN, 2007, p. 772).

18 Segundo esse teórico marxista, o mediador evanescente "funciona como um portador de mudança e transformação social, a ser relegado tão logo a mudança ratifique a realidade das instituições." (JAMESON, 1988, p. 26). (No original: "vanishing mediator serves as a bearer of change and social transformation, only to be forgotten once that change has ratified the reality of the institutions.").
} 
Elle parlait en phrases sobres

De la révolution d'Octobre

Je pensais déjà

Qu'après le tombeau de Lénine

On irait au cafe Pouchkine

Boire un chocolate. [... $]^{19}$

Há pouco de inédito na filosofia de descomprometimento político (leia-se "alienação", se quiser) que a letra francesa apresentada parece inspirar, isto é, na emolduração ideológica de um evento histórico como mero pano de fundo para a constituição ou reconciliação de um casal sob um impasse qualquer - o evento histórico em si é, por vezes, o impasse a ser superado. O cinema, cujo relacionamento íntimo com a ideologia era já sentida em 1924 por Anatóli Lunatcharsky dramaturgo pertencente à vanguarda artística do construtivismo russo, que esteve à frente do Narkompros soviético -, converteu-se, ao longo do século, no "instrumento natural" de sua mais ampla e eficaz veiculação (LUNATCHARSKY, 1994 [1924], p. 39-40; cf. FERRO, 1992, p. 27-29, 117-143; RAMONET, 1975, 2002; MERQUIOR, 1965, p. 201-203). Logo, convém fazer doravante as indagações benjaminianas de como a arte - ou teoria - cinematográfica se posiciona diante de determinadas lutas sociais e, sobretudo, de como ela própria funciona no seio dessas mesmas lutas. ${ }^{20}$

No filme The Fall of Berlin (1949), do soviético Mikheil Chiaureli, ninguém senão o próprio Stalin personifica o mito do velho sábio, um tanto metido a alcoviteiro, que instrui o operário Alexei a como dobrar de modo certeiro o coração da professora Natasha, "recitando-lhe poesia", ajudando a entender a pieguice de seus sentimentos, etc., justamente em meio à efusão da Grande Guerra Patriótica. Não é o Stalin, "o Terrível" quem atua aqui, mas o Stalin, "Pai dos Povos", o "Guia Genial dos Povos", como um tipo solene de Hitch, conselheiro amoroso (2005).

Hollywood é adepta por excelência de tal procedimento-e Hollywood aqui como "fantástica fábrica" de ideologia [Chocolate Factory]. Não à toa a produção cinematográfica hollywoodiana exercia verdadeiro fascínio sobre Stalin; e Hitler, sabe-se já há algum tempo, era obcecado pela vivacidade dos desenhos animados da Disney ${ }^{21}$ - de tudo reduzir a epifenômeno dramático de uma trama familiar,

\footnotetext{
19 A recusa persistente de Gilbert Bécaud em gravar a canção Nathalie, segundo revelação de Pierre Delanoë numa entrevista não muito antiga ("J'ai mis un an à convaincre Bécaud d'interpréter Nathalie"), não seria, antes, representativa do não rompimento com uma ideia de emancipação radical que a Revolução de 1917 instila, sobretudo diante do apregoado fracasso atual das democracias ditas representativas? A entrevista de Delanoë está disponível em: <https://goo.gl/Z8yyOm>. Acesso em: 11 maio 2017.

20 A propósito, no tocante à díade 'ideologia dominante' e 'ideologia que parece dominar' (ŽIŽEK, 2005a, p. 176).

21 É com não pouca ironia que Žižek (2011, p. 78) relata o plano de execução da Hollywood stalinista: "Boris Shumyastsky, chefe da produção cinematográfica soviética da década de 1930, visitou Hollywood e, impressionado, planejou construir uma Hollywood soviética no mar da Crimeia. Infelizmente, a descoberta no final da década de que ele era um agente imperialista impediu a execução desse nobre plano; em vez disso, o próprio Shumyatsky é que foi executado.". Há quem defenda, a partir de estudos dos Arquivos de Moscou, a tese de que o plano de execução da Hollywood stalinista quase vingou, mas não em terras soviéticas, e, sim, na própria Hollywood, que, uma vez controlada pelo Partido Comunista, teria deixado insinuar-se por agentes KGB e diretores e roteiristas simpatizantes, repercutindo o ideário comunista em prol da causa soviética e da subversão do "american way of life" durante a idade de ouro da produção cinematográfica americana (BILLINGSLEY, 1998; RADOSH; RADOSH, 2005). Demais disso, não custa recordar a presença de câmeras de filmagem em meio às aparições públicas do alto escalão nazista. A melhor corporificação do uso do cinema pelo nazismo fica por conta de Helene Bertha Amalie "Leni" Riefenstahl com seus Triumph des Willens (Triunfo da Vontade, 1934); e Olympia: 1) Feste der Völker (Festa dos Povos, 1936), e 2) Feste der Schönheit (Festa da Beleza, 1938), cuja inspiração foram o ambiente de uma sociedade armada para a guerra e os jogos
} 
Žižek (2011, p. 75) nos lembra: "tudo, do destino dos cavaleiros da Távola Redonda à Revolução de Outubro e aos asteroides que se chocam contra a terra, é transposto para a narrativa edipiana." Tal estruturação ideológica não falta a The Volga Boatmen (1928), a Doctor Zhivago (1965), nem a Reds (1981), ${ }^{22}$ tampouco a Burnt by the sun (1994), ${ }^{23}$ para ficar aqui apenas com quatro exemplares entre os épicos mais representativos. Mas a filmografia extra-hollywoodiana também parece participar do mesmo conceito. $\bigcirc$ filósofo esloveno suscita pelo menos duas produções genuinamente alemãs que repercutiriam a mesma lógica e enredo: Goodbye, Lenin! (2003), de Wolfgang Becker, e Das Leben der Anderen (2006), ${ }^{24}$ de Florian Henckel von Donnersmarck; cada uma, ao seu modo, reflete não uma "Fenomenologia do Espírito Comunista" - a aparição deste à consciência comum -, ${ }^{25}$ mas, acima de tudo, as repisadas peripécias da família até um sempre previsível desfecho apoteótico sentimental, em que pese ser a família mesma uma das mais primevas instituições sociais, na acepção de Durkheim (1983, p. 77).

A essa altura, não é porventura uma impertinência o questionar-se, por indução, acerca da natureza dessa "noção do Real histórico nos termos de uma narrativa familiar" (ŽIŽEK, 2011, P. 75): o que ela é em si mesma? A que se presta? O que lhe justifica teoricamente? Responder a tais

olímpicos de Berlim em 1936. Querendo-se uma leitura especializada sobre a direção de Riefenstahl - que, por sinal, também almejava o estrelato em Hollywood no início de sua carreira - em seus clássicos documentários, cf. Carvalho (2009).

22 No entanto, o crítico Robert Rosenstone (1982, p. 297-310), cuja premiada biografia sobre John Reed - Romantic Revolutionary, publicada em 1975 - subsidiou o enredo de Reds, embora ciente de que o próprio diretor sublinhasse, como o fizeram as propagandas e as resenhas à época, que o filme seja "basicamente uma história de amor", assevera que insistir nesse tema é não levar a obra a sério, ao acatar sua única dimensionalidade em detrimento do fato de ter sido "o primeiro filme americano a ter um comunista por herói, o primeiro a sugerir a existência de uma subcultura boêmia-radical durante o segundo decênio do século 20, o primeiro a insinuar pontos nevrálgicos que esmigalharam os movimentos radicais mundiais ao tempo da Revolução Russa, e certamente o primeiro a ter um casal genuinamente ianque debaixo do edredom ao som envolvente da Internacional." (No original: "Yet, as producer-director has insisted, as the advertisements have shown and the reviews have underscored, "Reds" is basically a love story. [...] To insist "Reds" is only a love story is to accept a kind of one-dimensionality, to deny the very real influence of motion pictures on our lives and to attempt to escape the implications of this powerful medium [...] It's the first Hollywood film to make a hero of a Communist, the first to suggest the existence of a bohemian-radical subculture during the second decade of the century, the first to hint at bitter issues that shattered world radical movements at the time of the Russian Revolution, and certainly the first to have an all-American couple bed down to the stirring strains of the "Internationale".).

${ }_{23}$ Em contraposição ao aludido The Fall of Berlin, Stalin não figura em Burnt by the sun como mediador evanescente entre o casal de personagens Kotov e Maroussia, embora compareça de modo fantasmático por meio de fotos em porta-retratos e estandartes soerguidos por balões. Kotov e Maroussia são abandonados aos humores do misterioso Mytia - que se assemelha ao obscuro Heathcliff de Wuthering Heights (1847) -, um típico anti-herói byroniano. À sua maneira, Žižek (2008, p. XX) fornece a clave lacaniana para se ler os desdobramentos do enredo a partir da entrada de figuras quejandas em cena: "[...] it is not a real-life person, but a fantasy-entity - the embodiment of the pure object-obstacle, that unfathomable ' $x$ ' of blind fate - which always, in a weird mixture of chance and inexorable necessity, as the necessity of a chance (a stroke of bad luck), intervenes to undermine the fulfilment of subjects' plans and intentions, guaranteeing that, one way or another, things will always somehow go wrong."

24 Em tempos em que se pode ter, após o clique de um mouse, a notícia instantânea acerca de qualquer cineasta e sua respectiva obra, mesmo do mais remoto rincão, aqui se furta, por isso mesmo, a fornecer sinopses dos filmes indicados, como o faz Žižek em seus livros, seguidas de análises que se servem o mais das vezes do modelo lacaniano. Nada obstante, o escrutínio filmográfico do filósofo esloveno se mostra ocasionalmente esquemático, menos por limitações intrínsecas ao modelo psicanalítico invocado do que por limitações de sua aplicação mesma. Dá-se um exemplo: Žižek indica que haveria uma "subcorrente homossexual secreta" em Das Leben der Anderen. O espião Gerd Wiesler seria, na sua opinião, "libidinalmente atraído" pelo escritor insurgente Georg Dreyman. Com a abnegada morte da atriz Christa-Maria Sieland, companheira de Dreyman, dar-se-ia, no melhor estilo Casablanca (1942), o "começo de uma bela amizade" entre ambos, "agora que o invasivo obstáculo feminino foi convenientemente descartado: um verdadeiro gesto de sacrifício cristológico. Não admira que seu nome seja Christa-Maria!” (ŽIŽEK, 2011, P. 82). CRÍTICO LITERÁRIO DE NOMEADA, O PROFESSOR ANTÔNIO CÂNDIDO HÁ MUITO ADVERTIA CONTRA A INFELICIDADE DE “CERTOS JOGOS VERBAIS EM MODA, COMO A INTEPRETAÇÃO SIMBÓLICA DOS NOMES PRÓPRIOS A PARTIR DA ETIMOLOGIA", QUE ACABA POR ERRAR O PRINCIPAL E, A PAR DISSO, NÃO FAZ PROGREDIR O CONHECIMENTO DA OBRA REPISADA, QUALQUER QUE SEJA ELA (CÂNDIDO, 2002, p. 58).

25 Nesse sentido, a respeito da "aparição" dos conceitos ou complexos teóricos fundamentais lacanianos, cf. Žižek (1992, p. XI). 
demandas exige um mínimo de compreensão filosófico-sociológica do atual estado de coisas: não há nada de mais notável na contemporaneidade que o seu ambivalente projeto de desutopia [Distopia], que consubstancia "não apenas a ausência temporária de Utopia, mas também a celebração do fim de todos os sonhos sociais" (DINERSTEIN; NEARY, 1998); um projeto cujos empreendedores lançam mão de tempo em demasia no tocante à desconstrução e à mobilização de remorso, recusa, esquecimento e anticrítica, não sem a companhia de justificações acadêmicas e catalogações científicas das abominações do século 20 (MCLAREN, 2000, p. XXV-XXVI).

[...] no momento em que mostramos o menor sinal de envolvimento em projetos políticos que parecem desafiar seriamente a ordem existente, a resposta é imediata: "Por mais benevolente que seja, isto inevitavelmente terminará num Gulag!". A função ideológica das constantes referências ao Holocausto, ao Gulag e às mais recentes catástrofes do Terceiro Mundo é, portanto, servir de apoio a este Denkverbot [proibição de pensar], ao nos lembrar constantemente como as coisas poderiam ter sido muito piores: "É só olhar em volta e ver por si mesmo o que irá acontecer se seguirmos suas ideias radicais!" (ŽIŽEK, 2005a, p. 174, grifo do autor). ${ }^{26}$

A confusão epistêmica entre os efeitos eventualmente funestos decorrentes de um levante revolucionário e a dimensão imanente propriamente dita do processo revolucionário, como ocorre entre críticos de índole conservadora (ou mesmo ditos de "esquerda"), tem engendrado um tipo de denúncia unânime, hoje em dia muito em voga, dos horrores da revolução. Essa ausência de percepção distintiva não seria, em todo caso, nenhuma novidade própria da era contemporânea que já não se encontrasse na precedente idade moderna: "todo o romantismo inglês", de acordo com um proeminente filósofo francês, "está repleto de uma reflexão sobre Cromwell muito análoga àquela que hoje se faz sobre Stálin." (DELEUZE, 1992, p. 211). A crença genérica de que a ideia de empreender revoluções não apenas resume um sonho lírico sem efetiva correspondência com a realidade histórica, mas também algo sempre nefasto ou nada auspicioso (e que deve ser repelida, por tudo o que há de mais sagrado, literalmente), ${ }^{27}$ segundo a mentalidade consensual liberal, é, em

\footnotetext{
26 No mesmo sentido, embora em outra obra sua: "[...] principalmente no domínio das relações socioeconômicas, nossa época se vê como se tivesse chegado à maturidade, quando, com o colapso dos Estados comunistas, a humanidade abandonou o velho sonho utópico milenarista e aceitou as restrições da realidade (leia-se a realidade socioeconômica capitalista) com todas as suas impossibilidades acessórias: Não se pode... participar de atos coletivos (que acabam necessariamente em terror totalitário), agarrar-se ao antigo Estado do bem-estar social (que nos torna pouco competitivos e provoca crises econômicas), isolar-se do mercado global etc. [...] Hoje, a ideologia dominante pretende nos fazer aceitar a 'impossibilidade' da mudança radical, da abolição do capitalismo, de uma democracia não limitada ao jogo parlamentar etc." (Z̈IŽEK, 2012b, p. 306, grifo do autor).

27 Certo filósofo alemão reparava consigo que os moralistas de todas as épocas jamais se perguntam como dourar, espiritualizar as paixões... "Antes, devido à estupidez na paixão, fazia-se guerra à paixão mesma: conspirava-se para aniquilá-la [...]. Aniquilar as paixões e os desejos apenas para evitar sua estupidez e as desagradáveis consequências de sua estupidez, isso nos parece, hoje apenas uma forma aguda de estupidez." (NIETZSCHE, 2006, p. 32-33, grifo do autor). Em uma de suas muitas idas à Bibliotèque Nationale, Benjamin houve por bem tomar notas do ensaio crítico de Chesterton sobre Dickens, ocasião em que registrou a disparidade, constatada pelo dito "príncipe do paradoxo", entre o temperamento do autor de Oliver Twist e o de seus concidadãos ingleses médios de então: estes ignoravam por completo a "razoável impaciência" que o animava a fazer suas denúncias, sempre com a primeira Revolução Francesa em mente. "O antigo radical não se considerava exatamente em estado de revolta: antes, achava que um certo número de instituições absurdas estavam em conflito com a razão e com ele próprio." (BENJAMIN, 2007, p. 811; cf. CHESTERTON, 1906, p. 235).
} 
verdade, um entrave cognitivo - oriundo do que se convencionou chamar, em filosofia da linguagem, de erro categorial [category mistake] - no tocante à compreensão das noções de "futuro das revoluções na história" e de "devir revolucionário das pessoas. Nem sequer são as mesmas pessoas nos dois casos. A única oportunidade dos homens está no devir revolucionário, o único que pode conjurar a vergonha ou responder ao intolerável." (DELEUZE, 1992, p. 211).

A desutopia deriva, afinal, não apenas do impreterível processo e sina modernas de racionalização e de desencantamento do mundo - die Entzauberung der Welt, no jargão de Weber (1982a) -, mas também da ambição do liberalismo em vistas da edificação contraleibniziana de um mundo "menos ruim possível", como supõe Jean-Claude Michéa (2007) em seu ensaio sobre a civilização liberal, que traz o sugestivo título L'Empire du moindre mal, em contraposição elíptica à célebre locução alemã die beste aller möglichen Welten ("o melhor dos mundos possíveis"). Esse filósofo do Hexágono junta-se ao coro de desconfiança de que o ideário liberal projeta, a rigor, uma tentativa de efetivação da "política do menos mal". Ou, se se quiser, dos males, o menor. Seria antes no afã de instituir o "reino do bem" que os partidários dessa política - ou talvez mundividência (Weltanschaaung) - creem residir a origem de todas as perversões da humanidade. Há um fundo pessimista, há talvez algo de maniqueu aqui. Uma profunda suspeita quanto à capacidade de se erigir uma outra realidade, mais razoável, mais "decente", por assim dizer. Comum em meio ao consenso liberal, a ojeriza contra aspirações utópicas, no sentido de uma reação ao questionamento da ordem sociopolítica vigente, acaba por não disfarçar um ódio secreto pelo gênero humano. Aqui é involuntário recordar, a mero título retórico, a indagação cristã: "Acaso teu olho é mal, porque eu sou bom?" (Evangelho de Mateus 20:15) (BÍBLIA, 1966).

Mas fazer guerra contra o pensamento do fanatismo moral - de que Robespierre "sentiase e confessava-se executor", Nietzsche (2004, p. 11-12) assim o acusa, de "fundar sobre a terra o império da sabedoria, da justiça e da virtude" -, como a pretendem fazer hoje os liberais, não seria de todo modo uma boa causa, uma coisa boa?! Em tal concepção de hostilidade subjaz uma repetição tautológica ${ }^{28}$ da negação do próprio ato - o "retorno do recalcado", na linguagem psicanalítica, ou seja, a reaparição ora distorcida dos conteúdos uma vez expulsos da consciência coletiva. Após refletir sobre o escrito de Michéa, Žižek descobre que o programa outrora minimalista de normas proibitivas da sujeição de uns aos outros tem se convertido numa complexa rede metarregulatória interminável (na acepção hegeliana de uma "schlechte Unendlichkeit" [infinidade espúria]), traduzida na atual luta contra todas as formas de opressão. A existência de uma luta nesses termos só pode ocorrer às expensas de uma condição artificial da mais extrema litigância. De "terrorismo" propriamente dito.

\footnotetext{
${ }_{28}$ O que se entende porventura com a esterilidade das tentativas de definição político-ideológica da arte, ante a infinda plasticidade de seu sentido. É digna de nota a lembrança do maestro Sérgio Magnani (1989, p. 23) de certo debate ocorrido nos Litoriais Universitários Fascistas acerca do tema Arte Fascista e Imperial: "alguém perguntou o que significaria arte fascista e imperial; e a resposta foi que "arte fascista e imperial" seria toda arte que não fosse pluto-judaico-maçônica. À segunda pergunta, sobre o que seria a arte "pluto-judaico-maçônica", a única resposta possível foi a de que seria ela toda arte que não fosse "fascista e imperial". A discussão, como é óbvio, não conseguiu sair deste impasse."
} 
Por indução, Nietzsche (2006, p. 82) aduz que o sofredor costuma prescrever para si mesmo, contra sua dor, o mel amargo da vingança; "um instinto causal é poderoso dentro dele: alguém deve ser o culpado por ele se encontrar mal [...]" Elege-se então a vítima; qualquer uma, a esmo. Em toda parte se encontram os objetos ocasionais dessa necessidade de vingança, também uma necessidade de prazer. Pouco importa se culpados ou inocentes. Os acusados hão de purgar, de qualquer modo, a impotência coletiva. ${ }^{29}$ Sua aridez, seu rebaixamento, sua indignidade. René Girard (2008, p. 5) chama devidamente esse fenômeno e predisposição pelo nome: linchamento unânime. Carnavalização bakthiana obscena. ${ }^{30}$ Sob a mesma insígnia filosófica hegeliana da "infinidade espúria", é possível entrever a vingança girardeana, que seria uma contradição social destruidora, vívida e infindável, pois "a vingança é um esforço para pôr fim à vingança."

Nesse aspecto preciso, nossa época moderna não diferiria, pois, da Antiguidade clássica, nem mesmo da Paleolítica. Estar-se-ia vivendo uma variação do estado pré-social em que se travava a velha "guerra de todos contra todos" [bellum omnia omnes], preconizada por Thomas Hobbes e presente, a contragosto porventura, na base mesma do pensamento liberal. Não faltariam exemplos de suscetibilidades alçadas à categoria de direitos coletivos fundamentais, supraconstitucionais, alvos de constantes "discriminações". Toda uma indústria da "discriminação" já está devidamente sentada à direita do capitalismo de mercado e não desacompanhada de linhas de montagem de produtos voltados exclusivamente ao consumo por parte de determinados nichos de "discriminados". ${ }^{1}$

\footnotetext{
${ }_{29}$ O mesmo fenômeno se transpõe à cinematografia e é talvez por ela melhor retratado: "Tecnicamente, busca-se um bode expiatório sobre o qual purgam-se os males. [...] Ditadores erigem seus discursos apontando bodes expiatórios palpáveis. 'Não falamos para dizer algo, mas apenas para produzir algum efeito', notava o ministro da propaganda de Hitler. Essa cousa chamada ser humano gosta de quem the aponta o bode a ser culpado, o que nos dá uma consciência de palpabilidade. Medo sem cara não serve. Le Bon, Freud, Wilhelm Reich, Elias Canetti e Ortega y Gasset falaram a mesma cousa com 15 anos de espaço: o povo se reúne e apoia o líder que lhe mostra o objeto sobre o qual purgaremos nossos medos. A tese de doutorado do jornalista Ignacio Ramonet, do Le Monde Diplomatique, escrita há tantos anos, diz melhor, e mais. Indica que, em épocas de crise, o cinema atrai o populacho purgando-lhe os medos reais com medos imaginários ainda mais terríveis. Foi depois da crise da Primeira Guerra Mundial que a República de Weimar [já enfraquecida] produziu o clima para Nosferatu, para Fritz Lang e para os terrores e monstruosidades em preto e branco de Murnau. Os monstros clássicos do cinema japonês, Gargula, Monstro da Bomba H, Godzilla, vieram depois de Hiroshima e Nagasaki. A crise do Petróleo de 73 gerou a primeira filmagem do Destino do Poseidon, Tubarão e Inferno na Torre, a partir de 1975. O medo da virada do milênio, de 2000 para 2001, nos trouxe Mar em Fúria e Independence Day. Hollywood também buscou outros panegíricos: quando a autoridade federal entra em crise nos EUA, a partir de 1973, com o caso Watergate, a indústria de cinema gringo convida as minorias a serem, nas telinhas, heróis federais: o tira grego Kojak, o tira negro Shaft, e os tiras italianos Columbo e Serpico." (TOGNOLLI, 2011).

30 Aqui a referência a Girard e a Bakthin não ocorre por acaso, à guisa de um tangenciamento do recorte temático. O conceito de "carnavalesco", que o filósofo russo herdou da tradição literária de seus conterrâneos - como Vissarion Belinsky, por exemplo - e delineou semanticamente (associando-o à noção de "grotesco") no decorrer da década de 1930, seria uma alusão, na opinião de Žižek (2008a, p. 350), "ao carnaval dos expurgos stalinistas." A expectativa de tais expurgos trazia consigo, segundo Sheila Fitzpatrick (1999, p. 20), uma espécie de "excitação à rotineira jornada de trabalho burocrático" nas fileiras do Partido (No original: "[...] similar purges were conducted in all government offices as well, bringing excitement into the workaday bureaucratic routine.").

31 Devemos a ideia e expressão insculpidas nessas três últimas orações ao Prof. Ruy Vasconcelos de Carvalho, quando das discussões em grupo sobre o ensaio de Michéa. Demais disso, a associação dos direitos das minorias com a noção de segmento de mercado não é gratuita aqui. Evelyne Pieiller (2017), da redação do Le Monde Diplomatique, especula - fundada na tese de Marcel Gauchet de que a ideia democrática vem se confundir com a ideia de uma sociedade política de mercado - que "o crescimento da demanda de reconhecimento pelo direito das diversas 'minorias'" contribuiria para uma dupla perda da soberania: a da nação, "como portadora da vontade geral", e a do povo, "porque transformaria os cidadãos em clientes singulares", em detrimento do "cidadão como abstração, desprovido de qualquer particularidade." (PIEILLER, 2017, p. 6). Por sua vez, a filósofa Nancy Fraser (2017), ao avaliar a eleição de Donald Trump como o novo presidente dos EUA, vislumbrou que seus eleitores não rejeitaram simplesmente o neoliberalismo propriamente dito, mas aquilo que ela denomina "neoliberalismo progressista",
} 
Na França, há associações de obesos que exigem a suspensão de todas as campanhas públicas contra a obesidade e a favor de alimentos alimentares saudáveis, porque elas ferem a autoestima dos obesos. Os militantes do Vegan Pride [Orgulho Vegano] condenam o "especismo" dos carnívoros (que discriminam os animais, privilegiando o animal humano, o que, para eles, é uma forma particularmente repugnante de "fascismo") e exigem que a "vegetofobia" seja tratada como um tipo de xenofobia e declarada crime. E poderíamos estender a lista para os que lutam pelos direitos do casamento incestuoso, do homicídio consensual e do canibalismo [...] (ŽZIŽEK, 2012b, p. 51).

Tem-se na citação apresentada um quadro decerto pitoresco da sociedade do "não-metoques" por excelência. De sorte que a tal "luta contra todas as formas de discriminação" esteja como que para sempre fadada ao anticlímax, dada a procrastinação contínua do desfecho ideal. Qual seria esse desfecho? O de finalmente alcançar "uma sociedade livre de todos os preconceitos morais", a qual, como explica Michéa (2007, p. 133-134), seria, por essa mesma razão, "uma sociedade condenada a ver crimes em tudo." ${ }^{32} \mathrm{Na}$ condição de discípulo de Lacan, em que pese à sua declarada heterodoxia, Žižek (2010, p. 31) sentir-se-ia bem tentado a diagnosticar que aí reside "a verdade da postura paranoica: ela própria é a trama destrutiva contra a qual está lutando."

Em que pé estamos hoje, então? Badiou caracterizou de modo memorável nossa difícil situação pós-socialista como "essa situação problemática em que vemos o mal dançando sobre as ruínas do mal". Não é questão de nostalgia; os regimes comunistas eram "maus", mas o problema é que aquilo que os substituiu também é "mau", embora de maneira diferente. [...] O que Badiou articula em termos teóricos confirma-se na experiência cotidiana da maioria das pessoas comuns: o colapso dos regimes comunistas não foi um evento no sentido de um rompimento histórico que dá origem a algo novo na história da emancipação. Depois do rompimento, as coisas simplesmente retornaram à normalidade capitalista [...] (ŽIŽEK, 2012b, p. 345-346).

projeto desutopista enfeixa esforços vigorosos, portanto, no sentido de retratar a Utopia como o imaginário político de uma cosmovisão romântica, nefelibata, naïve, antiquada, ${ }^{33}$ mas ameaçadora, nada obstante à destrutividade do Real capitalista. Por tal razão, denuncia-se que a Desutopia se sustenta apenas a partir da negação do conteúdo vital, ou seja, dos próprios fundamentos

o qual poderia ser entendido como mero oximoro e, assim, disfarçaria um "alinhamento político perverso." Em sua forma norte-americana, o assim chamado "neoliberalismo progressista" compreenderia uma aliança entre os "novos movimentos sociais" (feminismo, multiculturalismo e LGBT inclusos), de um lado, e setores comerciais "simbólicos" baseados em serviços ou de tecnologia de ponta (Wall Street, Vale do Silício e Hollywood), de outro. Ideias como "diversidade" e "empoderamento" seriam compartilhadas e manejadas nessa amálgama para fins político-econômicos e ideológicos os mais diversos (cf. FRASER, 2017, p. 281-284).

32 Em francês: "[...] il est inévitable que la notion de "crime" finisse, en droit, par pouvoir être apliquée à n'importe quel propos (tenu en privé ou en public) ou à n'importe quel comportement (allumer, par exemple, une cigarette dans la rue ou inviter les individus à surveiller leur équilibre alimentaire). Ce que [Lysander] Sponner n'avait visiblement pas prévu, c'est qu'une société libérée des tout les "préjuges"moraux, serait, du coup, condamnée à voir des crimes partout." (grifo do autor).

33 A impressão geral de que a tentativa imanente de estabelecimento de uma sociedade desprovida de classes sociais seria uma pretensão ultrapassada fica clara, segundo o filósofo alemão Christoph Türcke (1993, p. 38), na pergunta feita a Ernst Bloch, próximo ao fim da corrida espacial, se "socialismo e comunismo ainda (podem) ser atuais como forças motrizes cosmovisionais e históricas para uma humanidade que está a ponto de conquistar o universo." Ao que Bloch (1971, p. 32) respondeu, denunciando o geocentrismo do capital: "A terra nós temos de qualquer maneira - ela permanece e não desaparece. Todo nosso trabalho que nós fazemos acontece sob o ponto de vista ptolemaico." 
do mundo real (cf. DINERSTEIN e NEARY, 1998). A explicação psicanalítica contraintuitiva dessa atitude de hipocrisia - no sentido grego, para ficar aqui ainda no âmbito do léxico teatral - dos céticos quanto à viabilidade da Utopia na contemporaneidade pode se extrair da convergência entre os célebres aforismos lacanianos La verité a structure de fiction ("A verdade tem estrutura de ficção") ${ }^{34}$ e Les non-dupes errent ("Os não tolos erram"), ${ }^{35}$ isto é, aqueles que não se deixam enredar na ficção simbólica se enganam, e o fazem precisamente porque não percebem a sua eficiência, o modo como tal ficção conforma o real: "A necessidade estrutural que é carregada por toda expressão da verdade é justamente uma estrutura que é a mesma da ficção. A verdade tem uma estrutura, se podemos dizer, de ficção." (LACAN, 1995, p. 259).

This point becomes clearer through a particularly morbid joke. A patient in a large hospital room with many bed complains to the doctor about the constant noise that other patients are making, which is driving him crazy. The doctor replies that nothing can be done; one cannot forbid the patients from expressing their despair, since they all know they are dying. The first patient responds: 'Why don't you then put them in a separate room for dying'. The doctor replies calmly and glibly: 'But this is a room for those who are dying...' Why does everyone who knows a little bit about Hegel immediately discern this joke's 'Hegelian' flavour? It is precisely because of the final twist, in which the patient's subjetive position is undermined: he finds himself included in the very series from which he wanted to maintain distance. (ŽIŽEK, 2005B, P. 23).

Daí que os teóricos marxistas se debrucem insistentemente sobre a radicalidade anfibológica da ideologia comunista, da qual advém uma virtualidade emancipatória inclusive naquilo que ostente, por assim dizer, de mais "totalitário". Nessa senda, Žižek recorda uma cena de um filme soviético sobre a guerra civil na Rússia que assistira quando jovem na antiga Iugoslávia socialista, a fim de providenciar um exemplo de tal ambiguidade.

Da minha juventude, lembro-me da memorável cena de uma filme soviético sobre a guerra civil de 1919 na qual os bolcheviques organizam o julgamento público de uma mãe com um filho doente quem é acusada de ser espiã do Exército Branco contrarrevolucionário. Logo no início do julgamento, um velho bolchevique acaricia seu longo bigode branco e diz: "A sentença deve ser severa, mas justa!". A corte revolucionária (o coletivo dos combatentes bolcheviques) estabelece que a causa da atividade inimiga da mulher foram suas condições sociais difíceis; a sentença, portanto, é que ela deveria ser totalmente integrada no coletivo stalinista, aprender a ler e escrever e ter uma educação apropriada, enquanto seu filho seria entregue a cuidados médicos adequados. Quando a mãe, surpresa, incapaz de compreender a benevolência da corte, tem um acesso de choro, o velho bolchevique acaricia de novo seu bigode e balança a cabeça em sinal de aprovação: "Sim, é uma sentença severa, mas justa!" (ŽIŽEK, 2013a, p. 94-95).

\footnotetext{
34 Hoje em dia, sabe-se que em C'était un rendez-vous (1976) - aclamado curta-metragem no qual um motorista dirige em alta velocidade pelas ruas de uma Paris crepuscular - não havia nenhum possante da escuderia italiana, embora o próprio cartaz do filme à época retratasse, a partir de um ângulo raso, a lateral dianteira esquerda de uma glamourosa Ferrari 275GTB. 0 esportivo utilizado pelo diretor Claude Lelouch era, no caso, bem antifrancês, por assim dizer: uma Mercedes-Benz 450SEL 6.9. Só durante a pós-produção é que o som do motor da Mercedes foi "dublado" pelo da Ferrari. O filme, que é uma amostra do cinéma verité - a fotografia da realidade dita nua e crua -, parece comprovar a aludida sentença La verité a structure de fiction. 35 Máxima reformulada por Lacan, no Seminário 21, a partir do conceito "Noms-du-Père" de fundo freudiano - acerca do qual nos resguardamos de discutir aqui por interessar minimamente aos contornos deste trabalho -, preservando a homofonia original em francês.
} 
O filósofo esloveno está cônscio, por certo, de que essa perspectiva complacente assoma um tanto "pseudomarxista" ao falsear o terrorismo - não sem legitimá-lo ideologicamente, ainda que por contraste - típico dos "julgamentos-espetáculos" dos Processos de Moscou (a que se fazia expiação no filme), nos quais os dissidentes acusados é que tinham de se esforçar para negar os crimes que não cometeram perante o Comitê Central. Era um juízo de fachada; um palco alheio à possibilidade de inocência. ${ }^{36}$ Aqueles se resignavam ao mero cumprimento de um maquiavélico papel teatral, cujo personagem é forçado a encenar a participação na execração pública de sua própria figura. Todavia, a cena tal como descrita na reminiscência apresentada dá

aos espectadores novos padrões éticos pelos quais a realidade seria medida o resultado chocante desse exercício da justiça revolucionária, a inesperada recanalização da "severidade" em "severidade" para com as circunstâncias sociais e em generosidade para com as pessoas, não deixa de gerar um efeito sublime. (ŽIŽEK, 2013a, p. 95).

Uma amostra algo epifânica do potencial emancipatório revolucionário teria igualmente irrompido quando da representação do assalto ao Palácio de Inverno pelas forças revolucionárias bolcheviques - marco oficial da Revolução Russa -, quase três anos depois do acontecimento original, por uma ingente massa popular organizada de uma maneira tal que seus participantes não se resumiram a encenar papéis e roteiros decorados, mas se tornaram, antes, "um espetáculo para si mesmas". ${ }^{37}$

Considere a apresentação da Tomada do Palácio de Inverno encenada em Petrogrado por ocasião do terceiro aniversário da Revolução de Outubro (em 7 de novembro de 1920). Milhares de trabalhadores, soldados, estudantes e artistas trabalharam dia e noite, vivendo de kasha (um insosso mingau de trigo), chá e maçãs

\footnotetext{
36 Tais julgamentos eram marcados por um forte senso prévio de causa perdida, o que já vinha antecipado de modo de mais desalento em O Processo, de Kafka (2005, p. 99), escrito em 1920: "Ter um processo desses às costas significa já ter perdido." Diante de um tribunal estapafúrdio, o julgamento do inocente Josef K., cuja condenação é por todos pressentida, mostra-se mais um tipo de "paródia da justiça" - ela pretende ser justiça, enquanto é simplesmente a demonstração de poder bruto ou corrupção se fazendo passar por justiça." (ŽIŽEK, 2008b, p. 63). Há uma cena cômica no filme Judge Dredd (1995), na qual o personagem policialesco do ator Sylvester Stallone dá voz de prisão - pelo suposto crime de sabotagem dolosa de um androide público - a um hacker inofensivo, que havia apenas tentado se proteger, no interior de um expositor de bebidas futurístico, de um tiroteio selvagem entre gangues da Mega-Cidade Um: "Juiz Dredd: - Condenação automática a cinco anos de prisão. Como você se declara? Herman Fergusson: - Inocente?! Juiz Dredd: - Eu sabia que você iria dizer isso. Herman Fergusson: - Cinco anos?! Não! Não! Eu não tive chance! Eles estavam se matando lá fora! Juiz Dredd: - Você podia ter se atirado pela janela. Herman Fergusson: Quarenta andares?! Seria suicídio! Juiz Dredd: - Talvez. Mas é lícito." A ideia subjacente à sugestão de que o acusado dê cabo de sua própria vida (biológica, política, etc.) para escapar de um processo penal kafkiano é uma caricatura do sistema judiciário em seu aspecto mais ensandecido.

37 Cf. Lunatcharsky (apud TAYLOR, 2002, p. 8-9). (No original: "In order for the masses to make themselves felt, they must outwardly manifest themselves, and this is possible only when, to use Robespierre's phrase, they are their own spectacle [...] and thus, one can say: the whole people is manifesting its soul to itself."). Não seria justo, pois, tachar o caráter "sublime" deste evento, segundo Žižek (2008c, p. 283), com a pecha sintagmática benjaminiana de "estetização do político", típica das demonstrações no regime fascista.. Quanto à captura, ora na tela, do "espetacularismo da estética de massas", cf. Carvalho (2009). Querendo-se, todavia, uma leitura crítica quanto à participação popular das massas nesse episódio, leia-se Corney (2004, p. 70-96). E ainda a propósito dessa organização cênica das massas russas, não reprimimos a memória de uma passagem em que um filósofo anti-idealista se vale de uma tirada jocosa feita por Epicuro às custas de Platão e seus discípulos. Aquele costumava chamá-los de dionysikolakes: "Isto significa, literalmente e em primeiro lugar, 'aduladores de Dionísio', ou seja, clientes de tiranos e puxa-sacos servis; além de tudo quer dizer, porém, que 'são todos atores, nada neles é autêntico' (pois dionysikolax era uma denominação popular para ator)." (cf. NIETZSCHE, 2005a, p. 13). O efeito cômico do termo se acentua com a similitude onomástica entre Dionísio II - famoso tirano de Siracusa (367-357 a.C. e 346-344 a.C.), em cuja corte siciliana privava da amizade de Platão - e o deus da mitologia grega.
} 
congeladas para preparar a apresentação no mesmo lugar onde o acontecimento havia "realmente ocorrido" três anos antes. O trabalho foi coordenado por oficiais do Exército assim como artistas, músicos e diretores da vanguarda, de Malevich à Meyerhold. Apesar de ser uma encenação e não a "realidade", os soldados e marinheiros estavam representando a si mesmos - muito deles não apenas haviam realmente participado do acontecimento em 1917, mas também estavam, ao mesmo tempo, envolvidos nas batalhas reais da Guerra Civil que assolavam a vizinhança próxima a Petrogrado, uma cidade cercada sofrendo uma severa escassez de alimentos. Um contemporâneo comentou a apresentação: "Os historiadores do futuro se lembrarão de como, durante uma das revoluções mais sanguinárias e brutais, toda a Rússia estava encenando uma peça". E o teórico formalista Viktor Shklovski observou que "alguma espécie de processo elementar está acontecendo no local onde a viva fábrica da vida está sendo transformada na teatral". Todos nos lembramos das infames, auto-enaltecedoras, paradas de Primeiro de Maio que eram um dos sinais supremos de reconhecimento dos regimes estalinistas. Se alguém precisa de uma prova do quanto o leninismo funcionava de forma totalmente diferente, essas encenações não servem como prova suprema de que a Revolução de Outubro definitivamente não foi um simples coup d'etat de um pequeno grupo de um pequeno grupo bolchevista, mas um acontecimento que liberou um tremendo potencial emancipatório? (ŽlŽEK, 2008b, p. 282-283, grifo do autor)..$^{38}$

A partir de uma evidência de autocompreensão do tipo "empaticamente revivencial" (WEBER, 1980 , p. 2) $)^{39}$ por parte dos atores russos outrora atores da Revolução encenada, não se verificou, ao que consta, na ocasião da representação apresentada, o costumeiro uso do espírito revolucionário como mote para a arte cinematográfica, mas, à guisa de inversão, o próprio espírito revolucionário é que teria manejado a arte cinematográfica a fim de canalizar sua expressão imanente. ${ }^{40}$ Logo, o encargo teórico do materialismo histórico - ou, em grau abstrato, da historiografia crítica contemporânea - é menos um empreendimento de desconstrução derridiana, no caso, das urdiduras familiares

\footnotetext{
38 A tomada do Palácio de Inverno não foi, contudo, expressão de uma "exuberante orgia da violência revolucionária destrutiva", como o que faz entender Žižek (2008c, p. 284) com base nas impressões de Serguei Eisenstein expostas na cena de seu filme Outubro (1927), em que os revolucionários vitoriosos se põem a "quebrar", sem um sentido aparente, "milhares de garrafas de vinho extremamente caras." Os relatos históricos apontam, antes, a uma orgia carnavalizante bakhtiana, como se vê do trecho a seguir: [...] os guardas vermelhos nunca "atacaram" o Palácio de Inverno, apenas subiram sem oposição por portas ou janelas destrancadas e muitos foram direto para as caves de vinho, as mais luxuosas da história. Cada novo destacamento da Guarda Vermelha enviado para impedir um saque também se embebedou. "Tentamos inundar os porões com água", relembrou o líder das forças bolcheviques no local, "mas os bombeiros [...] também se embebedaram." (KOTKIN, 2017, p. 238). No mesmo sentido de um pouco heroico e nada acirrado assalto ao Palácio de Inverno, vide Fitzpatrick (1994, p. 64).

39 No original: "Alle Deutung strebt, wie alle Wissenschaft überhaupt, nach "Evidenz". Evidenz des Verstehens kann entweder: [a)] rationalen (und alsdann entweder logischen oder mathematischen), oder [b)] einfühlend nacherlebenden (emotionalen, künstlerischrezeptiven) Charakters sein. Rational evident ist auf dem Gebiet des Handelns vor allem das in seinem gemeinten Sinnzusammenhang restlos und durchsichtig intellektuell Verstandene. Einfühlend evident ist am Handeln das in seinem erlebten Gefühlszusammenhang voll Nacherlebte."

40 Contudo, em ensaio - até hoje referencial - devotado à celebre cineasta nazista, Susan Sontag fez pouco da "ingenuidade" de quem insiste em catalogar de modo distintivo as produções mais marcantes de Riefenstahl como "documentários", e não como "propaganda" propriamente dita. De modo a corroborar seu argumento, segue a denunciar que nelas não há simples registro da realidade, mas antes, disposição da realidade a serviço da imagem: "In her book published in 1935, Riefenstahl had told the truth. The Nuremberg Rally'was planned not only as a spectacular mass meeting - but as a spectacular propaganda film [...] The ceremonies and precise plans of the parades, marches, processions, the architecture of the halls and stadium were designed for the convenience of the cameras.' How the Party convention was staged was determined by the decision to produce Triumph of the Will. The event, instead of being an end in itself, served as the set of a film which was then to assume the character of an authentic documentary. Anyone who defends Riefenstahl's films as documentaries, if documentary is to be distinguished from propaganda, is being ingenuous. In Triumph of the Will, the document (the image) is no longer simply the record of reality; 'reality' has been constructed to serve the image." (SONTAG, 1975).
} 
encenadas no transcorrer ou mesmo no auge de um evento histórico traumático, ou geralmente em prol de uma rearticulação positivista da história sob a perspectiva metodológica da tradição rankeana - insculpida no vetusto brocardo alemão "wie es eigentlich gewesen" -, e mais uma retomada ${ }^{41}$ da "potencialidade oculta (o potencial utópico emancipador) que foi traída na realidade da revolução e em seu resultado final (o capitalismo utilitário de mercado)." (Žižek, 2011, p. 75). Ou seja, o sujeito histórico não deve se interessar pelo passado como realmente foi, mas pelo presente em vista do futuro como poderia ter sido.

Durante as filmagens de Doutor Jivago de David Lean, em um dos subúrbios de Madrid em 1964, uma multidão de estadistas espanhóis tinha que cantar a "Internationale" em uma cena que envolvia uma demonstração de massas. A equipe do filme ficou surpresa ao descobrir que todos conheciam a música e a cantavam com tamanha paixão que a polícia franquista interviu, pensando que estavam lidando com uma manifestação política verdadeira. Mais ainda, tarde da noite (a cena deveria se passar na escuridão), ao ouvir os ecos da música, pessoas que viviam em casas próximas abriram garrafas de bebida e começaram a dançar nas ruas, presumindo, erroneamente, que Franco havia morrido e os socialistas tomado o poder. Este livro é dedicado a esses momentos mágicos de liberdade ilusória (que, de certo modo, não eram simplesmente ilusórios) e às esperanças frustradas pelo retorno à realidade "normal". (ŽIŽEK, 2008b, p. 12-13, grifo do autor) ${ }^{42}$

Noutro episódio, hoje icônico - considerado "a quarta pior decisão da história da filmografia", de acordo com a Total Film, revista britânica devotada especialmente ao cinema -, o diretor de Reds, Warren Beatty, houve por bem dar aulas aos figurantes russos acerca da exploração capitalista e do imperialismo ianque, a fim de inspirá-los e, dessa forma, capturar maior fidedignidade nos sets. Assim como Bernardo Bertolucci esperava da atriz Maria Schneider, na controversa cena do estupro em Last tango in Paris (1972), Beatty não pretendia que os atores apenas encenassem o pathos da alienação, mas que sentissem na pele a própria alienação; os figurantes então captaram devidamente a mensagem: a certa altura das filmagens, todos entraram em greve exigindo cachês mais dignos. ${ }^{43}$

Daí que de suas impressões originais acerca das pretensões de ação do marxismo (práxis) - com que travara o primeiro contato por meio de História e Consciência de Classe, de Lukács, lido

\footnotetext{
$\overline{41}$ No sentido filosófico de Kierkegaard [Gjentagelsen, no original]. Constantemente traduzido por "repetição", a contragosto do autor, já que esse último termo tende a aludir a uma "reprodução do Velho", e não, como queria o filósofo dinamarquês, a "um movimento para a frente, a produção do Novo." (ŽIŽEK, 2008c, p. 29-30). O literato sueco Arne Melberg reforça o argumento: o termo "repetição" se inclina a indicar "a movement in time: re-take, re-peat, re-turn, re-verse means going back in time to what 'has been'." (MELBERG, 1990, p. 73).

42 O maestro Sérgio Magnani (1989, p. 22, grifo do autor) conta dessa vez, a propósito do perene dilema filosófico acerca do engajamento do artista ou da arte propriamente dita, que "Verdi, quando escreveu o coro de Os Lombardos na primeira Cruzada, quis apenas criar uma expressiva e bem construída página coral. Todavia, quando a ópera foi repetida no Teatro alla Scala [sic], em 1848, este coro soou como o hino da revolução de Milão. Os milaneses reconheceram na paixão daquele canto a paixão patriótica da nação; sentiram que a luta medieval dos lombardos era a luta eterna do oprimido contra o opressor; e foram, diretamente, do teatro às barricadas, cantando com Verdi O Signor che dal tetto natio ci chiamasti con santa promessa. Evidentemente, o espírito de Verdi estava tão profundamente consubstanciado daqueles ideais de liberdade e de pátria, que a sua mensagem artística os veiculava intuitivamente e os comunicava através dos misteriosos canais que ligam os grandes criadores à sensibilidade das massas." (1989, p. 22, itálico no original). Essa é uma manobra que Hegel ficaria inclinado a denominar "astúcia da Razão" [die List der Vernunft].

43 Disponível em: <https://goo.gl/pqoHpj>. Acesso em: 10 maio 2017.
} 
em 1926 -, Walter Benjamin não houve por bem reproduzir, como se lê em suas teses sobre o conceito de história, a clássica noção ideológica da revolução (comunista) como padrão inerente a ser naturalmente alcançado no decurso da história. Para ele, revolução significava sobretudo interrupção fortuita e premente de uma sucessão episódica interminável de catástrofes. $\bigcirc$ anseio de que, caso contrário, tudo estará perdido. "44 "Socialismo ou barbárie", como na famosa palavra de ordem de Rosa Luxemburgo (1974, p. 23). Um tipo intelectual de pessimismo premonitório. 45 "Marx diz que as revoluções são a locomotiva da história mundial. Mas talvez a coisa seja completamente diferente" e aqui fala o instinto de autoconservação sob a pressão de uma pressentida autodestruição vindoura: "Talvez as revoluções sejam o lançar mão do freio de emergência por parte da raça humana que viaja neste trem." (BENJAMIN, 1974, p. 1232). ${ }^{46}$

These VI - Vergangenes historisch artikulieren heißt nicht, es erkennes "wie es denn eigentlich gewesen ist". Es heißt, sich einer Erinnerung bemächtigen, wie sie im Augenblick einer Gefahr aufblitzt. Dem historischen Materialismus geht es darum, ein Bild der Vergangenheit festzuhalten, wie es sich im Augenblick der Gefahr dem historischen Subjekt unversehens einstellt. Die Gefahr droht sowohl dem Bestand der Tradition wie ihren Empfängern. Für beide ist sie ein und dieselbe: sich zum Werkzeug der herrschenden Klasse herzugeben. In jeder Epoche muß versucht werden, die überlieferung von neuem dem Konformismus abzugewinnen, der im Begriff steht, sie zu überwältigen. Der Messias kommt ja nicht nur als der Erlöser; er kommt als der Oberwinder des Antichrist. Nur dem Geschichtsschreiber wohnt die Gabe bei, im Vergangenen den Funken der Hoffnung anzufachen, der davon durchdrungen ist: auch die Toten werden vor dem Feind, wenn er siegt, nicht sicher sein. Und dieser Feind hat zu siegen nicht aufgehört. (BENJAMIN, 1980, p. 695). ${ }^{47}$

\footnotetext{
44 Esse pathos escatológico que engendra uma sensação de urgência do ato revolucionário parecia envolver o espírito leninista nos idos de 1917: "[Lênin] estava tão longe quanto possível de qualquer confiança na 'necessidade histórica' (eram seus adversários mencheviques que insistiam que é possível pular a sucessão de estágios prescritos pelo determinismo histórico: primeiro o democrático-burguês, depois a revolução proletária...). Nas 'Teses de abril' de 1917, quando Lenin descobriu o Augenblick, a oportunidade única de revolução, suas propostas foram recebidas com estupor ou desprezo pela maioria de seus colegas de partido. Dentro do partido bolchevique, nenhum líder importante apoiou seu chamado à revolução, е о Pravda [Правда] deu um passo extraordinário, desassociando o partido e o conselho editorial das 'Teses de abril' de Lenin; longe de ser uma bajulação oportunista e de aproveitar o clima predominante no partido, as opiniões de Lenin eram altamente idiossincrásicas. Bogdanov qualificou as 'Teses de abril' como 'delírio de louco', e mesmo Nadejda Krupskaia concluiu: 'temo que pareça que Lenin enlouqueceu'. Lenin percebeu imediatamente a oportunidade revolucionária que surgiu de circunstâncias contingentes únicas: se o momento não fosse aproveitado, a oportunidade de fazer a revolução se perderia, talvez durante décadas. Temos então o próprio Lenin imaginando um roteiro alternativo: 'E se não agirmos agora?' - e foi exatamente a consciência das consequências catastróficas de não agir que o levou a agir... Mas há um compromisso muito mais profundo com histórias alternativas de um ponto de vista marxista radical: ele leva a lógica do 'e se' à sua inversão autorreflexiva. Para o marxista radical, a história real que vivemos é em si um tipo de história alternativa realizada, a realidade em que temos que viver, porque não aproveitamos o momento no passado e não agimos." (ŽIŽEK, 2012b, p. 99, grifo do autor). É curioso notar que parte desse trecho de Žižek foi reproduzido quase que fielmente pelo historiador americano Stephen Kotkin $(2017$, p. 22) em certa página de sua obra mais recente sobre Stálin.

45 "É por perceber esse perigo catastrófico que ele evoca (no artigo sobre o Surrealismo em 1929) o pessimismo - um pessimismo revolucionário que não tem nada a ver com a resignação fatalista e, menos ainda, com o Kulturpessimismus alemão, conservador, reacionário e pré-fascista de Carl Schmitt, Oswald Spengler ou Moeler van der Bruck; o pessimismo está aqui a serviço da emancipação das classes oprimidas." (LÖWY, 2005, p. 23).

${ }^{46}$ No original: "Marx sagt, die Revolutionen sind die Lokomotiven der Weltgeschichte. Aber vielleicht ist dem gänzlich anders. Vielleicht sind die Revolutionen der Griff des in diesem Zuge reisenden Menschengeschlechts nach der Notbremse."

47 Há uma excelente tradução em português das teses benjaminianas sobre o conceito de história, esta também inclusa em Löwy (2005, p. 65), a saber: "Tese VI - Articular o passado historicamente não significa conhecê-lo 'tal como ele propriamente foi'. Significa apoderar-se de uma lembrança tal como ela lampeja num instante de perigo. Importa ao materialismo histórico capturar uma imagem do passado como ela inesperadamente se coloca para o sujeito histórico no instante do perigo. O perigo ameaça tanto o conteúdo dado da tradição quanto os seus destinatários. Para ambos o perigo é único e o mesmo: deixar-se transformar em instrumento da classe dominante. Em cada época é preciso tentar arrancar a transmissão da tradição ao
} 
A tarefa teorética de retomada do "Evento-Lênin" e da "Ideia de Comunismo"48 tem exigido, portanto, que pelo menos dois filósofos europeus entre os marxistas mais expressivos, Slavoj Žižek e Alain Badiou, empenhem hoje, respectivamente, toda a sua força de abstração. Uma vez que certa experiência da promessa emancipatória - ao lado de uma ideia de messianismo, justiça e de democracia -, enquanto noção espectral, é alçada também por Derrida à própria condição indescontrutível da desconstrução, ${ }^{49}$ o estatuto de tal referência não se coadunaria com a Ideia reguladora em sua acepção kantiano-hegeliana: "uma Ideia que está no processo da própria realização" (ŽIŽEK, 2012b, p. 355-356), ou seja, uma ideia não reduzida a uma ordem positiva do Ser, não ontologizada, a "tensão incoercível para um futuro ideal e necessário" de que falara o jovem Buarque (2016, p. 330)?

"Lenin" não é um nome nostálgico para uma velha certeza dogmática; pelo contrário, o Lenin que deve ser recuperado é o Lenin que teve como experiência fundamental ser jogado numa nova e catastrófica constelação, na qual as velhas coordenadas se provaram inúteis, e que foi compelido a reinventar o marxismo - podemos citar este duro comentário sobre um novo tema: "A esse respeito, Marx e Engels não disseram uma só palavra". A ideia não é retornar a Lenin, mas repeti-lo no sentido kierkegaardiano: recuperar o mesmo impulso na constelação atual. O retorno a Lenin não pretende ser uma reencenação nostálgica dos "bons velhos tempos revolucionários", nem um ajuste oportunista-pragmático do velho programa para "novas condições"; busca, isto sim, repetir, nas condições do mundo atual, o gesto leninista que reinventou o projeto revolucionário na época do imperialismo e do colonialismo [...]. "Lenin" representa a liberdade imperativa de suspender as deterioradas coordenadas (pós-)ideológicas existentes, a debilitante Denkverbot (proibição de pensar) na qual vivemos - simplesmente significa que temos permissão para pensar novamente. [...] Por isso, repetir Lenin não significa retornar a Lenin - repetir Lenin é aceitar que "Lenin esteja morto", que a solução proposta por ele fracassou, e até que fracassou monstruosamente, mas que havia uma chama utópica ali que vale a pena guardar. Repetir Lenin significa que temos de distinguir o que ele fez do campo de possibilidades que abriu, a tensão em Lenin entre o que ele fez e outra dimensão: aquilo que "em Lenin era maior do que o próprio Lenin". Repetir Lenin é repetir não o que Lenin fez, mas o que ele não conseguiu fazer, suas oportunidades perdidas. (ŽIŽEK, 2005a, p. $15-16$ e 341 , grifo do autor). ${ }^{50}$

Conquanto a intervenção pessoal de Lênin tenha sido porventura indispensável à efetivação da Revolução Russa - "First things first. Without Lenin there would have been no socialist revolution in

\footnotetext{
conformismo que está na iminência de subjuga-la. Pois o Messias não vem somente como redentor; ele vem como vencedor do Anticristo. $O$ dom de atear ao passado a centelha da esperança pertence apenas ao historiador que está perpassando pela conviç̧ão de que também os mortos não estarão seguros diante do inimigo, se ele for vitorioso. E esse inimigo não tem cessado de vencer."

48 Querendo-se um maior aprofundamento acerca de ambos os conceitos ("Evento" e "Ideia"), cf. Žižek (2008a, p. 223-227) e Badiou (2012, p. 129-148).

49 "Well, what remains irreducible to any deconstruction, what remains as undeconstructible as the possibility itself of deconstruction is, perhaps, a certain experience of the emancipatory promise; it is perhaps even the formality of a structural messianism, a messianism without religion, even a messianic without messianism, an idea of justice - which we distinguish from law or right and even from human rights - and an idea of democracy - which we distinguish from its current concept and from its determined predicates today." (DERRIDA, 1994, p. 74).

50 Atentar para a nota de rodapé em que se discute a tradução e sentido do termo filosófico Gjentagelsen de Søren Kierkegaard.
} 
1917. Of this much we can be certain." (ALI, 2017, p. 13) -, retomá-lo não tem o condão, esclareça-se, de pretender um reavivamento atávico do culto personalista, do carisma típico do caudilhismo, tanto mais em um país como o Brasil em que a tradição autoritária mais floresceu e deitou raízes. E aqui as ideias de Žižek guardam afinidade com as impressões de certo scholar em história do leste europeu, para quem o velho enfoque em um Lênin como líder partidário inquestionável e mero orquestrador de um golpe de Estado é uma abordagem política que perde o liame do que realmente aconteceu (WHITE, 2004, p. 187). A história da Revolução de Outubro não é a história carlyleana de um gênio ou herói solitário; ${ }^{51}$ seu triunfo reside, antes, no que se convencionou chamar de micropolítica revolucionária, isto é, "a incrível explosão da democracia popular, de comitês locais se insurgindo em torno de todas as grandes cidades da Rússia e ignorando a autoridade do governo 'legítimo', tomando a situação em suas próprias mãos. Essa é a história não contada da Revolução de Outubro [...]" (ŽIŽEK, 2005a, p. 11). Uma história que Kotkin (2017, p. 214) reconta, ao seu modo conservador, como que incitada por um tipo de fanatismo lendário e espontâneo, uma unanimidade espiritual na cena política russa, a qual vivia, à época, "sob a tirania das ideias fixas."

Já em nossa era, designada por Habermas (1985, p. 118) como "A nova Opacidade" [die neue Unübersichtlichkeit], em que o programa do Estado Social é incapaz de debuxar "possibilidades futuras de uma vida colectivamemente melhor e menos ameaçada", impera, todavia, uma preferência ético-política como que unânime pelo modelo democrático em geral, a despeito de qualquer de suas contradições imanentes; ${ }^{52}$ uma fetichização em que o sujeito da fantasia se mostra incapaz de tomar "o arcabouço institucional democrático do Estado (burguês)" como objeto de crítica, a qual se restringe superficialmente a tímidas propostas de "democratizar o capitalismo, aumentar o controle democrático sobre a economia, por meio da pressão da mídia, de inquéritos parlamentares, regras

\footnotetext{
51 Querendo-se uma imagem da personalidade de Lênin e de sua influência, vide Kotkin (2017, p. 238-240); esse historiador chega a registrar que, aos olhos de seus camaradas e contemporâneos, "Lênin parecia encarnar a vontade política." (KOTKIN, 2017, p. 241). Sobre a atualidade da Revolução de Outubro como o cerne mesmo do pensamento de Lênin, cf. Lukács (2009, p. 9-14). Sobre Lênin como um espécime de "gênio revolucionário", cf. Schapiro (1967, p. 8 e ss). O próprio Trotsky (1958, p. 53-54, grifo do autor) anota em seu diário, em passagem do dia 25 de março de 1935, a seguinte confidência: "For the sake of clarity I would put it this way. Had I not been present in 1917 in Petersburg, the October Revolution would still have taken place - on the condition that Lenin was present and in command. If neither Lenin nor I had been present in Petersburg, there would have been no October Revolution: the leadership of the Bolshevik Party would have prevented it from occurring-of this I have not the slightest doubt! If Lenin had not been in Petersburg, I doubt whether I could have managed to conquer the resistance of the Bolshevik leaders." Ao se debruçar sobre o livro Lénine, de Hélène Carrère d'Encausse, Žižek (2002, p. 14) nota que essa historiadora francesa ressalta "corretamente" que o gênio do líder soviético jazia "in his ability to move beyond the typical narrative of the revolution, in which a brief, ecstatic explosion of utopian energy is followed by a sobering morning after. Lenin possessed the strength to prolong the utopian moment." Nessa mesma obra recenseada por Žižek (2002, p. 14), Lênin - e não apenas Lênin, mas toda a gente de seu entorno - assoma curiosamente com um aspecto que conjuga algo do inconformismo furtivo beatnik e da indolência dos rois fainéants, como se lê da impressão seguinte: "In their very triviality, the details of the Bolshevilks' daily lives in 1917 and the following years make it obvious how different they were from the Stalinist nomenklature. Leaving his flat for the Smolny Institute, on the evening of October 24, 1917, Lenin took a tram and asked the conductress if there was any fighting going on in the city center that day. In the years immediately after the October Revolution, he mostly traveled around in a car with only his driver and bodyguard Gil for protection; they were shot at, stopped by the police and arrested (the policemen did not recognize Lenin). Once, after a visit to a school in the suburbs, bandits posing as police stole the car, and Lenin and Gil had to walk to the nearest police station to report the theft. On August 30, 1918, Lenin was shot while talking to workers outside a factory he had just visited. Gil drove him to the Kremlin, where there were no doctors; Nadezhda Krupskaya suggested that someone should run out to the nearest grocer's shop for a lemon." Contudo, uma visão crítica de Lênin e seus feitos políticos se encontra em Wilson (2006, p. 548 e ss.).

52 Cf. Patologias da Democracia, de Pieiller (2017, p. 6-7).
} 
mais duras, investigações policiais etc." (ŽIŽEK, 2012b, p. 330). Ou, quando muito, resume-se a sugestões de mudança do sistema de governo, de um já encalacrado presidencialismo, dizem, a um parlamentarismo cada vez mais pujante (VALENZUELA, 2004). Seria esta também uma "ideia fixa" ? Ao largo de tal dilema, Alain Badiou dele se subtrai ${ }^{53}$ ao preferir a retomada do comunismo como acontecimento emancipatório novo com singularidade universal: sua novidade não teria se exaurido com a obsolescência de seu valor de surpresa (cujo Virtual não foi, com efeito, compreendido quando de sua aparição primeira). Logo, o Novo não se trata aqui de uma realidade fenomênica inédita, mas da percepção do potencial Virtual de tal realidade a partir da transcendência das condições históricas nas quais ela se engendrou. À noção de retomada subjaz, portanto, segundo Žižek (2013b, p. 100), o encargo ambivalente da teoria materialista-histórica contemporânea, a saber:

de um lado, [retomar] a "crítica da economia política" marxista sem a noção utópico-ideológica do comunismo como padrão inerente; de outro, imaginar uma verdadeira ruptura do horizonte capitalista, sem cair na armadilha de retornar à noção eminentemente pré-moderna de uma sociedade equilibrada e (auto)contida.

Para o filósofo esloveno, o modo de seleção do governo não seria digno de maiores interesses, "mas a pressão exercida sobre ele pela mobilização e pela auto-organização do povo." (ŽIŽEK, 2012b, p. 282). No entanto, ele reconhece que tais problemas teóricos - concernentes à realização efetiva da democracia comunista, por assim dizer - repercutem com persistência no âmbito da práxis e na agenda revolucionária do sujeito histórico: "como institucionalizar a tomada coletiva de decisões para além do arcabouço da democracia multipartidária? Quem será o agente dessa reinvenção? Ou, para colocar de maneira brutal, quem sabe o que fazer atualmente?" (ŽĽŽEK, 2012a, p. 93). Essa derradeira indagação, que insinua a célebre reflexão leninista ("O que fazer?") quanto à práxis, sua formulação e desdobramentos no Real, acena a um método - talvez mais frutífero - de inversão lógico-objectal do questionamento bastante corriqueiro acerca do valor-relevância de determinada figura ou obra históricas para gerações posteriores. No caso, em vez da significância de Lênin para os tempos hodiernos, o que esta nossa época poderia, afinal, significar para Lênin?

Hoje, Lenin parece alguém que veio de outra era: não é que suas ideias sobre um partido centralizado, e assim por diante, possam constituir uma "ameaça totalitária"; na verdade, elas parecem pertencer a uma época diferente, com a qual não conseguimos nos identificar adequadamente. Entretanto, em vez de interpretar esse fato como prova de que Lenin ficou obsoleto, devemos talvez arriscar uma conjectura na direção oposta: e se essa impenetrabilidade de Lenin for um sinal de que há algo errado com nossa época? E se o fato de considerarmos Lenin irrelevante, "fora de sincronia" com nosso tempo pós-moderno, revelar de modo incômodo que nosso próprio tempo pós-moderno está "fora de sincronia", que uma certa dimensão histórica está desaparecendo? (ŽIŽEK, 2005a, p. 341, grifo do autor).

\footnotetext{
53 "If democracy means representation, it is first of all the representation of the general system that bears its forms. In other words: electoral democracy is only representative in so far as it is first of all the consensual representation of capitalism, or of what today has been renamed the "market economy". This is its underlying corruption." (BADIOU, 2010, p. 91).
} 


\section{Conclusão}

Ao refletir sobre os sentidos da estética caipira, Cândido (1993, p. 251) lamentava que esta viesse sofrida não de influências "normais" e "orgânicas", à guisa de suas congêneres ditas cultas, mas antes de uma "deformação caricatural e alienante que a desfigura, e que corrompe o gosto médio como vingança involuntária do espoliado contra o seu espoliador.” (1993, p. 251). Tal escrutínio bem poderia se aplicar à Revolução Russa. Ela talvez sofra dos mesmos influxos, à vista do exposto anteriormente. Há, pois, de se recuperar revoluções. Nelas no que há de mais visceral. Para além da mera ressunção de sua mensagem pelos constantes "retornos" e revisionismos muito em voga nalguns círculos intelectuais, em forma de catequese com ares de novidade (LOSURDO, 2002, p. 3-35, 2017, p. 9-43). Urge retomar-lhes a autenticidade - não sair à cata de seu sentido originalmente puro, o sociólogo da arte não deve fazer as vezes de antiquário -, aquilo que tem de monádico, por assim dizer, sua quintessência em face a uma estética cujos objetos se sucedem em acelerado processo expansivo, tanto mais a um fetiche de espectador pela representação de reviravoltas sociais como geral e grosseiramente ambicionam que estas sejam, ainda nas palavras de Candido (1993, p. 251), "mais ou menos caricaturad[as] para espetáculo dos outros."

E embora Lênin e a Revolução de Outubro possam estar há muito sepultados, ${ }^{54}$ sua morte tem algo da morte consumadora de que Zaratustra predicava: uma morte que não se quer jamais esgotada, e, por essa razão, ela "se torna um aguilhão e uma promessa para os vivos. [...] Morrer assim é a melhor coisa; mas a segunda melhor é morrer na luta e prodigalizar uma grande alma." (NIETZSCHE, 2011, p. 69). ${ }^{55}$

É preciso, uma vez mais, e talvez com a maior das premências, permitir-se a utopia de erigir uma nova ordem, um mundo novo, embora não pelas mãos de sonhadores quixotescos, com que se constroem castelos nos ares para neles se domiciliar. "Não existe um grão de utopia em Marx; ele não inventa, não idealiza, peça por peça, uma sociedade 'nova'. Não; ele estuda [...] o nascimento da nova sociedade a partir da velha, as formas de transição desta para aquela. [...] Nós não somos utopistas. Não sonhamos [...]", é Lênin (1970, p. 55, grifo do autor) mesmo quem o assevera, aquele que, dentre os marxistas de maior proeminência, "era o menos deslumbrado por visões proféticas, o

\footnotetext{
54 "Lenin's corpse remains in its mausoleum in Red Square (minus the honor guard and the November parades), one suspects, more for reasons of government inertia than Communist mystique. But can October ever be over? Its reduction and distillation to a symbol surely fixes its place in Russia's and the world's historical memory. In future crises, this symbol may well find itself invoked once more, to be embraced or denied. Indeed, perhaps October is still with us, if by another name." (CORNEY, 2004, p. 221). Ou, para suscitar a frase arrematadora com que o historiador inglês Orlando Figes (1998, p. 824) concluiu certa obra sua: "The ghosts of 1917 have not been laid to rest.". Por fim, inspirado pela morte do líder russo em 1924, Maiakovski (2012, p. 27) lhe dedicou nesse mesmo ano um poema épico com mais de três mil versos, entre os quais comparece a seguinte consolação aos camaradas: "Não devemos / nos derramar / em poços de lágrimas, - / Lenin / ainda / está mais vivo do que os vivos."

55 Zaratustra recria aqui, à guisa de inversão, o pessimismo contido na sabedoria oracular do deus grego Sileno, que, reza a lenda, teria dito a um Midas obsequioso de saber qual dentre as coisas era a melhor e a mais preferível para o homem: "Por que me obrigas a dizer-te o que seria para ti mais salutar não ouvir? O melhor de tudo é para ti inteiramente inatingível: não ter nascido, não ser, nada ser. Depois disso, porém, o melhor para ti é logo morrer." (NIETZSCHE, 1992, p. 36, grifo do autor).
} 
que de pronto reajustava seus prospectos." (WILSON, 2003, p. 467). ${ }^{56}$ Foi precisamente em virtude da concretude do estado de possibilidade real de mudança social que Marx, envolvido por inteiro com a análise crítica do agora e, por isso, bastante despreocupado com a imaginação de predicativos e enfeites do Porvir, deu à sua obra-prima o título de $O$ Capital, e não, por exemplo, como nota Ernst Bloch, de Convocação para o socialismo.

Faltam conscientemente as adjetivações propriamente ditas do futuro, conforme foi exposto acima, e faltam conscientemente pela exata razão de que toda a obra de Marx serve ao futuro, sim, porque na realidade só pode ser compreendida e concretizada no horizonte do futuro, mas não como futuro pintado em cores abstrato-utópicas. Pelo contrário, como futuro que é iluminado de forma materialista-histórico sob e a partir do passado e da atualidade, portanto, das tendências atuantes e persistentes, a fim de ser dessa maneira um futuro conscientemente moldável. [...] pois lembremos: o marxismo não é uma antecipação (função utópica), mas o novo de uma antecipação concreta ligada ao processo. Da mesma maneira, justamente em razão, disso, faz parte do marxismo que o entusiasmo e a sobriedade, consciência do alvo e análise dos dados reais andem de mãos dadas. (BLOCH, 2006, p. 175-176, grifo do autor).

Agora não aparenta senão um tanto incongruente o quadro de "uma certa casta de intelectuais, particularmente russos", pintados por Weber com a paleta conceitual de Simmel, envoltos em cores rubras de um romantismo excitadíssimo mas estéril, levado a cabo, segundo o sociólogo, por apaixonados políticos desprovidos de qualquer senso de responsabilidade objetiva. Esse pathos moscovita andava causando, todavia, verdadeiro frenesi à época, sobretudo nos círculos intelectuais alemães, "obnubilados por esse carnaval a que se concede o nome pomposo de "revolução" (WEBER, 1982b, p. 138). Não à toa Perry Anderson (1992, p. 182-197) duvidava, comungando ideias quejandas de Merleau-Ponty (2006 [1955], p. 23-29), que A Política como Vocação, proferida originalmente na Universidade de Munique, em 28 de janeiro de 1919, fosse conferência acadêmica desinteressada, como Weber pretendia e dava a entender logo no início dessa sua preleção; sobressairia no texto, a despeito da almejada "objetividade" do conhecimento, uma forte retórica e sentimento nacionalistas e antirrevolucionários. Seriam Rosa Luxemburgo e Karl Liebknecht, tombados no então recente Spartakusaufstand, durante os desdobramentos finais da Revolução Alemã de 1918-1919, os modelos da paixão árida [sterile Aufregung] que o retratista de Heidelberg tinha em mente nesse texto, por acaso? A fim de ilustrar as dimensões da tensão entre meios e fins, típica do meandros da política,

\footnotetext{
56 No original: "[...] we must remember that of all the, great Marxists he was least in love with prophetic visions, most readily readjusted his prospects." Em todo caso, um Karl Popper (2002, p. 291-416) não chancelaria, mais tarde, em sua fase liberal, essa visão pragmática acerca do marxismo (em sua opinião, o ideário de um "falso profeta"), cujos traços utópicos remontariam às ideias comunistas de Platão. E como se percebe no trecho a seguir, o escritor e político checo Václav Havel (2002, p. XIII) aparentava ser de mesma opinião: "I come from a country that lived under a Communist regime for several decades. On the basis of my own experience, I can therefore confirm that Sir Karl Popper was right. In the beginning was an allegedly scientific theory of historical laws; that Marxist theory subsequently gave rise to Communist utopia, the vision of a paradise on Earth, and the latter produced the gulags, the endless suffering of many nations, the endless violation of the human being." Querendo-se, todavia, uma análise do conceito de "utopia concreta" [Konkrete Utopie], desenvolvido por Ernst Bloch - primeiramente em Geist der Utopie (1918) e amadurecido em Das Prinzip Hoffnung (1959) -, para quem o marxismo, embora diverso das utopias abstratas, seria também um herdeiro dessa tradição, leia-se Löwy (2015, p. 245-252).
} 
Weber se permite elucubrar, a certa altura de sua palestra, um enunciado algo maiêtico acerca do que entende ser um dilema ambivalente dos socialistas zimmerwaldianos. Estes, em questionados se prefeririam a perduração da guerra seguida da revolução ou se a paz imediata conquanto desacompanhada da revolução, escolheriam, por certo, a continuidade da peleja.

E à pergunta: "O que pode trazer essa revolução?", todo socialista dotado de conhecimentos científicos responderia: não podemos falar de uma transição para uma economia que, em nosso sentido, fosse chamada de socialista; ressurgirá uma economia burguesa, apenas sem os elementos feudais e os vestígios dinásticos. Para esse resultado tão modesto, eles estão dispostos a enfrentar "mais alguns anos de guerra". Bem poderíamos dizer que mesmo com uma convicção socialista muito robusta rejeitaríamos uma finalidade que exige tais meios. Com o bolchevismo e o espartacismo e, em geral, com qualquer tipo de socialismo revolucionário, é precisamente o mesmo. (WEBER, 1982b, p. 145).

O pecado que o sociólogo comete, percebe-se, é o de compreender o ato político assim meramente pragmático, proveniente de uma ética de resultados, a que chama de "finalidade substantiva"; o revolucionário dedicado a uma causa imbuída de uma principiologia libertária, o qual se arremessa contra a ordem e a ideologia que lhe dá sustentáculo, mas que adiante jaz morto ou vencido, posta à prova sua "eficácia”, significa, para Weber (1982a, p. 138), apenas um irresponsável, carente de "objetividade" e de "senso de proporção", porquanto embevecido de uma paixão política inautêntica. ${ }^{57}$ Weber não vislumbra tal ato como um tipo de juramento, uma afirmação do compromisso incondicional para com a ideia imanente de liberdade; não enxerga a tentativa como já um sucesso em si, porque lhe falta a apreensão da "ideia com todo o seu peso platônico." (ŽIŽEK, 2012 b, p. 16). Nesses termos, nenhuma luta se faz em vão.

Weber carece, porém, um tanto mais além das lições de Platão. Falta-lhe Aristóteles também, passeios peripatéticos, belvederes, um cesto da gávea que seja, qualquer posto elevado cujo esforço de ascensão lhe recompense, ao final, com uma vista panorâmica, uma perspectiva em tudo mais ampla que o interior da alcova onde repousa enquanto elabora e passa a limpo sua conferência; pois parece ter sido a preferência por seus aposentos que lhe fez sentir bem à vontade para emitir juízos sobre à dinâmica revolucionária, à semelhança do criado de quarto de Hegel: "Ninguém é herói para seu criado-de-quarto; não porque o herói não seja um herói, mas porque o criado-de-quarto é criado-de-quarto, com quem o herói nada tem a ver enquanto herói, mas [só] enquanto homem que come, bebe e se veste." (HEGEL, 1992, p. 137). Weber não enxerga a dimensão universal da ação concreta, de tal modo constituída que a individualidade "preencha por si mesma essa universalidade mostrando-se, por isso mesmo, capaz de algo mais elevado." Ele a contrapõe, antes, à sua outra

\footnotetext{
57 Em contraposição a esse tipo de política, Žižek (2012b, p. 16) invoca o aforismo de Badiou: "Mieux vaut un desástre qu'un désêtre", isto é, mais vale correr o risco e engajar-se em fidelidade num Evento-Verdade, mesmo que essa fidelidade termine em catástrofe, do que vegetar na sobrevivência hedonista-utilitária sem eventos daqueles que Nietzsche chamou de "últimos homens". Portanto, o que Badiou rejeita é a ideologia liberal da vitimação, que leva a política a evitar o pior, a renunciar a todos os projetos positivos e buscar a opção menos pior. Ou como observou com amargura o escritor vienense Arthur Feldman: o preço que costumamos pagar pela sobrevivência é a nossa vida."
} 
dimensão de singularidade e de individualidade, explica-a "por sua intenção - que é diferente da ação mesma - e por sua motivação egoística"; na consciência judicante de Weber prepondera a consideração da particularidade da ação; acaba assim por desempenhar "para com aquele-que-age o [papel de] criado-de-quarto da moralidade." (HEGEL, 1992, p. 137-138, grifo do autor).

De toda forma, é o próprio Weber (1982b, p. 153) quem curiosamente empresta ao encerramento de sua conferência aos universitários bávaros um tom conclamatório - "toda experiência histórica confirma a verdade que o homem não teria alcançado o possível se repetidas vezes não tivesse tentado o impossível" - de inspiração estilística aparentada à parábola final do Humano, demasiado humano de Nietzsche (2005b, p. 270-271). Esse desfecho é digno de nota, porque seria novamente lido 50 anos depois, dessa vez de modo aforístico e bem menos cerimonioso, em meio ao fervor dos eventos de maio de 1968, estampado em forma de grafite nos muros da Sorbonne: Soyons realistes, demadons l'impossible! (MARCUSE, 1969, p. 20). Os manuscritos de Weber teriam mesmo deixado a inquietude dos átrios da Universidade de Munique para se inscreverem, revoltosos, nas paredes externas da Universidade de Paris? Com efeito, soa um tanto insólita e até inadmissível entre certos guardiões dos cânones da "vanguarda revolucionária", sejam estes acadêmicos ou militantes partidários, a conjectura de que o pensamento sociológico weberiano ("idealista", "conservadorista"...) pudesse ter antecipado ou mesmo concebido alguma vez o lema de um levante popular marcadamente radical. ${ }^{58}$ Não se trata aqui de uma absurda licença poética: é óbvio que os estudantes franceses não se sublevaram porque inspirados nos escritos de Max Weber. Quer-se dizer apenas que estes já insinuariam paradoxalmente ${ }^{59}$ algo do "esprit de Mai", sua perspectiva alvissareira quanto à factibilidade da utopia para todo aquele se investe em uma sobriedade heroica, armado com uma "fortaleza de coração que pode enfrentar até mesmo o desmoronar de todas as esperanças. Isso é necessário neste momento, ou os homens não poderão alcançar nem mesmo aquilo que é possível hoje." (WEBER, 1982b, p. 153).

Suposições à parte, ficamos, à guisa da conclusão de A ética protestante e o "espírito" do capitalismo $0^{60}$ - tão reconhecidamente destoante segundo o juízo de seu próprio autor que Löwy (2014, p. 46-52) costuma encará-la como uma "digressão crítica" arrematadora -, ${ }^{61}$ com certa reminiscência

\footnotetext{
58 "Im Vertrauen Kreise pflegte Max Weber öfter zu sagen: das nationale Unglück Deutschlands sei, daß man noch nie einen Hohenzollern geköpft hat." (LUKÁCS, 1966, p. 16). Tradução dos autores: "Max Weber costumava segredar, em círculos íntimos, que a infelicidade nacional alemã era a de nunca haver decapitado alguém da casa de Hohenzollern."

59 O leitmotiv sociológico da obra weberiana reaparece constantemente como caracterizador das relações capitalistas como horizonte insuperável das relações sociais (MÉSZÁROS, 2011, p. 409-410). De acordo com o próprio Weber (1982c, p. 265), a ideia de suprimir tal panorama assomaria "cada vez mais utópica."

60 Para entender as sutilezas do porquê do termo "Espírito" comparecer entre aspas na edição da Companhia das Letras, assim como na original, Pierucci (2004, p. 7).

61 O desfecho dessa obra, de remarcada densidade subjetiva, parece contrastar com a própria noção de inevitabilidade do capitalismo, concebido pelo sociólogo como uma sina iniludível na vida moderna ["dieser 'Unvermeidlichkeit' unserer wirtschaftlichen Entwicklung" (WEBER, 1996, p. 99)]: "Ninguém sabe ainda quem no futuro vai viver sob essa crosta e se ao cabo desse desenvolvimento monstro hão de surgir profetas inteiramente novos, ou um vigoroso nascer de velhas ideias e antigos ideais, ou - se nem uma coisa nem outra - o que vai restar não será uma petrificação chinesa" [ou melhor: mecanizada], arrematada com uma espécie convulsiva de autossuficiência. Então, para os 'últimos homens' desse desenvolvimento cultural, bem poderiam tornar-se verdade as palavras: "Especialistas sem espírito, gozadores sem coração: esse Nada imagina ter chegado a um grau de humanidade nunca antes alcançado." (WEBER, 2004, p. 166). A declaração seguinte comparece logo após a essa famosa
} 
de Kundera, de um estranho enternecimento que sentira quando folheava a esmo um livro sobre Hitler: ao se deparar com algumas de suas fotografias, comoveu-se. Não pelo ditador, naturalmente! Mas pela sua infância que se arrastou na guerra, os parentes e amigos que morreram nos campos de concentração nazistas... o que era tudo isso comparado a uma fotografia de Hitler, que lhe fazia lembrar da juventude perdida de sua vida, de um tempo que nunca mais haveria de voltar? (KUNDERA, 2008, p. 10). Retomar a Revolução de Outubro e seu intrínseco potencial emancipatório radical é dar vida nova a essa desesperança política na história. ${ }^{62}$ Ou então não é nada.

\section{Referências}

AGAMBEN, Giorgio. Meios sem fim: notas sobre a política. Belo Horizonte: Autêntica, 2015.

ALI, Tariq. The Dilemmas of Lenin: Terrorism, War, Empire, Love, Rebellion. London: Verso Books, 2017.

ANDERSON, Perry. Max Weber and Ernest Gellner: Science, Politics, Enchantment. In: ANDERSON, Perry. A Zone of Engagement. London: Verso Books, 1992. p. 182-197.

ARON, Raymond. O ópio dos intelectuais. São Paulo: Três Estrelas, 2016.

BADIOU, Alain. A hipótese comunista. São Paulo: Boitempo, 2012.

BADIOU, Alain. The meaning of Sarkozy. London: Verso Books, 2010.

BASKHAR, Roy. A Realist Theory of Science. London: Routledge, 2008.

BENJAMIN, Walter. Notizen und Vorarbeiten zu den Thesen Über den Begriff der Geschichte. In: BENJAMIN, Walter. Gessammelter Schriften, ders. R. Tiedemann e H. Schweppenhäuser, vol. I, 3. Frankfurt am Main, 1974.

BENJAMIN, Walter. Passagens. Belo Horizonte: Editora UFMG, 2007.

BENJAMIN, Walter. Über den Begriff der Geschichte. In: BENJAMIN, Walter. Gesammelte Schrifte. Band I-2. Frankfurt: Suhrkamp, 1980.

BÍBLIA. Evangelho de Mateus. In: BÍBLIA. Bíblia sagrada: contendo o antigo e o novo testamento. Tradução João Ferreira de Almeida. Rio de Janeiro: Sociedade Bíblica do Brasil, 1966.

apóstrofe: "Mas com isso ingressamos no terreno dos juízos de valor e juízos de fé, com os quais esta exposição puramente histórica não deve ser onerada." (WEBER, 2004, p. 166).

62 "In the words of historian Alan Kimball, the still unrealized "dream" of revolution in Soviet Russia ensured that the October epic had to be "sung and sung again" in the pursuit of ultimate success. All those who tried to harness October to new ends were animated by a belief in the need to maintain its mythic stature among the Soviet people." (CORNEY, 2004, p. 220). Ou, como instruía Wilson (2006, p. 548), a respeito de seu Rumo à Estação Finlândia, que devia ser lido - nada obstante a um "tom excessivamente esperançoso" - como um 'relato basicamente confiável do que os revolucionários julgavam estar fazendo em prol de "um mundo melhor'." Daí que Ramonet (2011) tenha se sentido um tanto compelido, logo após a queda das torres gêmeas e o estupor que tomou os EUA quando do 11 de Setembro, a fazer a seguinte conclamação contraweberiana: "Chegou a hora de reinventar a política e reencantar o mundo." Algo que Weber mesmo chamaria, se não chamou, talvez com palavras diversas e em outras lições ou conferências, de Wiederverzauberung der Welt. 
BILLINGSLEY, Kenneth Lloyd. Hollywood Party: How Communism Seduced the American Film Industry in the 1930s and 1940s. Rocklin, California: Forum, 1998.

BLOCH, Ernst. Im Christentum steckt die Revolte. Zurich: Verlag Die Arche, 1971.

BLOCH, Ernst. O Princípio Esperança. Rio de Janeiro: EdUERJ: Contraponto, 2006. v. 2.

CALLINICOS, Alex. Leninism in the Twenty-First Century? Lenin, Weber, and the Politics of Responsibility. In: BUDGEN, Sebastian; KOUVELAKIS, Stathis; ŽIŽEK, Slavoj (Ed.). Lenin Reloaded: Towards a Politics of Truth. Durham and London, Duke University Press, 2007.

CANDIDO, Antonio. Recortes. São Paulo: Companhia das Letras, 1993.

CANDIDO, Antonio. Textos de intervenção. São Paulo: Livraria Duas Cidades Ltda, 2002. (Coleção Espírito Crítico).

CARVALHO, Ruy Vasconcelos de. A cineasta de Hitler. Afetivagem, 30 maio 2009. Disponível em: <http://afetivagem.blogspot.com.br/2009/05/cineasta-de-hitler.html>. Acesso em: 10 jun. 2017.

CHESTERTON, Gilbert Keith. Charles Dickens: A Critical Study. New York: Dodd Mead \& Company, 1906.

COPI, Irving M. Introdução à lógica. São Paulo: Mestre Jou, 1978.

CORNEY, Frederick C. Telling October: Memory and the Making of the Bolshevik Revolution. Ithaca: Cornell University Press, 2004.

DEBORD, Guy. A sociedade do espetáculo: comentários à sociedade do espetáculo. Rio de Janeiro: Editora Contraponto, 1997.

DELEUZE, Gilles. Conversações: 1972-1990. São Paulo: Ed. 34, 1992.

DERRIDA, Jacques. Specters of Marx: The State of the Debt, the Work of Mourning and The New International. New York: Routledge, 1994.

DINERSTEIN, Ana C.; NEARY, Michael. Class struggle and the Communist Manifesto. Conference to Celebrate 150 Years of the Communist Manifesto, Paris, May 1998. Disponível em: <http://www. espaces-marx.eu.org/Archives/Marx_98/Contributions/Autre.../Dinerstein.htm >. Acesso em: 05 maio 2017.

DÜRKHEIM, Emile. As regras do método sociológico. São Paulo: Abril Cultural, 1983. (Coleção Os Pensadores).

FAIRCLOUGH, Norman. Analysing Discourse: Textual analysis for social research. London: Routledge, 2003.

FERRO, Marc. Cinema e História. São Paulo: Paz e Terra, 1992.

FIGES, Orlando. A People's Tragedy: The Russian Revolution (1891-1924). New York: Penguin Books, 1998.

FITZPATRICK, Sheila. Everyday Stalinism. New York: Oxford University Press, 1999. 
FITZPATRICK, Sheila. The Russian Revolution. New York: Oxford University Press, 1994.

FRASER, Nancy. Progressive Neoliberalism versus Reactionary Populism: a choice that feminists should refuse. Nora - Nordic Journal of Feminist and Gender Research, v. 24, n. 4, p. 281-284, 24 Feb. 2017.

GIRARD, René. O bode expiatório e Deus. Covilhã: Lusosofia Press, 2008.

HABERMAS, Jürgen. A nova Opacidade: a crise do Estado-Providência e o esgotamento das energias utópicas. Revista de Comunicação e Linguagens, n. 2, p. 115-128, 1985.

HAVEL, Václav. Preface: Karl Popper's The Open Society and Its Enemies in the contemporary global word. In: POPPER, Karl. The Open Society and Its Enemies. London: Routledge, 2002.

HEGEL, G. W. F. A Fenomenologia do Espírito (parte II). Petrópolis: Vozes, 1992.

HILL, Christopher. Lênin e a Revolução Russa. Rio de Janeiro: Zahar Editôres, 1967.

HOLANDA, Sérgio Buarque de. Raízes do Brasil. São Paulo: Companhia das Letras, 2016.

JAMESON, Frederic. The Vanishing Mediator; or Max Weber as Storyteller. In: Ders. The Ideologies of Theory. Essays 1971-1986, Bd. 2: The Syntax of History, University of Minnesota Press, 1988.

KAFKA, Franz. O Processo. São Paulo: Companhia das Letras, 2005.

KERSHAW, Ian; LEWIN, Moshe. Stalinism and Nazism: dictatorship in comparison. Cambridge: Cambridge University Press, 1997.

KOTKIN, Stephen Mark. Stálin: Paradoxos do poder (1878-1928). São Paulo: Objetiva, 2017. v. 1.

KUNDERA, Milan. A insustentável leveza do ser. São Paulo: Companhia das Letras, 2008.

LACAN, Jacques. O Seminário de Jacques Lacan, livro 4: As Relações de Objeto. Rio de Janeiro: Jorge Zahar Editor, 1995.

LÊNIN, V. I. O Estado e a Revolução. Tradução J. Ferreira. Porto: Vale Formoso, 1970.

LÉVI-STRAUSS, Claude. Tristes trópicos. Tradução Wilson Martins. Revisão Lévi-Strauss. São Paulo: Anhembi Limitada, 1957.

LIESSMANN, Konrad Paul. Geleitwort: Der tote Hund. Affektenlehre und amor Dei intellectualis: Die Rezeption Spinozas im Deutschen Idealismus, in der Frühromantik und in der Gegenwart. Herausgeben von Violetta L. Waibel. Hamburg: Felix Meiner Verlag GmbH, 2012.

LOSURDO, Domenico. Guerra e Revolução: o mundo um século após Outubro de 1917. São Paulo: Boitempo, 2017.

LOSURDO, Domenico. Il resivionismo storico: problemi e miti. 5. ed. Roma: Laterza, 2002.

LÖWY, Michel. A jaula de aço: Max Weber e o marxismo weberiano: São Paulo: Boitempo, 2014. 
LÖWY, Michel; SAYRE, Robert. Revolta e Melancolia. São Paulo: Boitempo, 2015.

LÖWY, Michel. Walter Benjamin: aviso de incêndio / Uma leitura das teses "Sobre o conceito de história”. São Paulo: Boitempo, 2005.

LUKÁCS, György. Lenin: A Study on the Unity of His Thought. London: Verso Books, 2009.

LUKÁCS, György. Vom Nietzsche bis Hitler. Frankfurt: Fischer, 1966.

LUNATCHARSKY, Anatoli. "Revolutionary Ideology and Cinema - Theses". In: CHRISTIE, Ian. The Film Factory: Russian and Soviet Cinema in Documents 1896-1939. New York: Routledge, 1994.

LUXEMBURGO, Rosa. A crise da social-democracia. São Paulo: Martins Fontes, 1974.

MAIAKOVSKI, Vladimir. Vladimir Ilitch Lenin: poema. Tradução Zoia Ribeiro Prestes. São Paulo: Anita Garibaldi, Fundação Maurício Grabois, 2012.

MAGNANI, Sérgio. Expressão e Comunicação na Linguagem da Música. Belo Horizonte: Editora UFMG, 1989.

MARCUSE, Herbert. Das Ende der Utopie: Vorträge und Diskussionen in Berlin 1967. Frankfurt: Neue Kritik, 1980.

MARCUSE, Herbert. The Realm of Freedom and the Realm of Necessity: A Reconsideration. Praxis: a Philosophical Journal, Zagreb, v. 5, p. 20-25, 1969.

MARX, Karl. Das Kapital. MEW. Erster Band. Berlin: Dietz Verlag, 1969.

MARX, Karl. Marx an Ludwig Kugelmann. MEW. Band 32. Berlin: Dietz Verlag, 1965.

MCLAREN, Peter. Che Guevara, Paulo Freire and the Pedagogy of Revolution. Oxford, Rowan \& Littlefield Inc., 2000.

MELBERG, Arne. Repetition (In the Kierkegaardian Sense of the Term). Diacritics, v. 20, n. 3, p. 71-87, Autumn, 1990.

MERLEAU-PONTY, Maurice. As aventuras da dialética. São Paulo: Martins Fontes, 2006.

MERQUIOR, José Guilherme. Notas soltas sobre o declínio da aura. In: MERQUIOR, José Guilherme. A Razão do Poema: ensaios de crítica e de estética. Rio de Janeiro: Civilização Brasileira, 1965. p. 201-203.

MÉSZÁROS, Ístvan. Para além do capital. São Paulo: Boitempo, 2011.

MICHÉA, Jean-Claude. L'Empire du moindre mal: essai sur la civilization libérale. Paris: Climats, 2007.

MIÉVILLE, China. October. London: Verso Books, 2017.

NIETZSCHE, Friedrich. Além do Bem e do Mal. São Paulo: Companhia das Letras, 2005a. 
NIETZSCHE, Friedrich. Assim falou Zaratustra. São Paulo: Companhia das Letras, 2011.

NIETZSCHE, Friedrich. Aurora. São Paulo: Companhia das Letras, 2004.

NIETZSCHE, Friedrich. Humano, demasiado humano. São Paulo: Companhia das Letras, 2005b.

NIETZSCHE, Friedrich. O Crepúsculo dos Ídolos. São Paulo: Companhia das Letras, 2006.

NIETZSCHE, Friedrich. O nascimento da tragédia. São Paulo: Companhia das Letras, 1992.

ORWELL, George. O que é fascismo? E outros ensaios. São Paulo: Companhia das Letras, 2017.

PIEILLER, Evelyne. Patologias da democracia. Le Monde Diplomatique Brasil, a. 10, n. 119, p. 6-7, jun. 2017.

PIERUCCI, Antônio Flávio. Apresentação. In: WEBER, Max. A ética protestante e o "espírito" do capitalismo. São Paulo: Companhia das Letras, 2004.

POPPER, Karl. The Open Society and Its Enemies. London: Routledge, 2002.

RADOSH, Ronald; RADOSH, Allis. Red Star Over Hollywood: The Film Colony's Long Romance with the Left. New York, Encounter Books, 2005.

RAMONET, Ignacio. Images soufflées. Le Monde Diplomatique, France, Mai 1975. Disponível em: <https://www.monde-diplomatique.fr/1975/05/RAMONET/33155>. Acesso em: 09 jun. 2017.

RAMONET, Ignacio. O novo sistema mundo. Le Monde Diplomatique, Edição Portuguesa, 21 out. 2011. Disponível em: <https://pt.mondediplo.com/spip.php?article835>. Acesso em: 09 jun. 2017.

RAMONET, Ignacio. Propagandas silenciosas: massas, televisão, cinema. Petrópolis: Vozes, 2002.

ROSENSTONE, Robert A. Reds as history. Reviews in American History, v. 10, n. 3, p. 297-310, Sept. 1982.

ROUSSO, Henry (Ed.). Stalinism and Nazism: history and memory compared. Lincoln and London: University of Nebraska Press, 2004.

SALEM, Jean. Lenin y la revolución. Barcelona: Ediciones Península, 2010.

SCHAPIRO, Leonard Bethram. Lenin after Fifty Years. In: SCHAPIRO, Leonard; REDDAWAY, Peter. (Ed.). Lenin, The Man, The Theorist, The Leader: A Reappraisal. London School of Economics, 1967.

SONTAG, Susan. Fascinating Fascism. New York Book of Reviews, v. 22, n. 1, Feb 6, 1975. Disponível em: <http://www.nybooks.com/articles/1975/02/06/fascinating-fascism/>. Acesso em: 10 jun. 2017.

TAYLOR, Richard. October. London: British Film Institut, 2002. 
TOGNOLLI, Cláudio Júlio. Medo e Angústia. Brasil 247, 05 abr. 2011. Disponível em: <http:// www.brasil247.com/pt/247/cultura/935/Medo-e-ang\%C3\%BAstia-Ozzy-Osbourne.htm >. Acesso em: 09 jun. 2017.

TROTSKY, Leon. Trotsky's Diary in Exile: 1935. Tradução Elena Zarudnaya. London: Faber and Faber, 1958.

TÜRCKE, Christoph. O Louco: Nietzsche e a mania da razão. Petrópolis: Vozes, 1993.

VALENZUELA, Arturo. Latin America presidencies interrupted. Journal of Democracy, v. 15, n. 4, p. 5-19, Oct. 2004.

WEBER, Max. A Ciência como Vocação. In: WEBER, Max. Ensaios de Sociologia. Rio de Janeiro: LTC Editora, 1982a. p. 154-186.

WEBER, Max. A ética protestante e o "espirito" do capitalismo. São Paulo: Companhia das Letras, 2004.

WEBER, Max. A Política como Vocação. In: WEBER, Max. Ensaios de Sociologia. Rio de Janeiro: LTC Editora, 1982b. p. 97-153.

WEBER, Max. Burocracia. In: WEBER, Max. Ensaios de Sociologia. Rio de Janeiro: LTC Editora, 1982c. p. 229-282.

WEBER, Max. Wirtschaft und Gesellschaft. 5. Aufl. Tübingen: J.C.B. Mohr (Paul Siebeck), 1980.

WEBER, Max. Zur Lage der bürgerlichen Demokratie in Rußland. In: WEBER, Max. Zur Russischen Revolution von 1905: Schriften und Reden 1905-1912. Tübingen: J.C.B Mohr (Paul Siebeck), 1996, Bd. 10.

WILSON, Edmund. Prefácio à edição de 1971. In: WILSON, Edmund. Rumo à Estação Finlândia. São Paulo: Companhia das Letras, 2006.

WILSON, Edmund. To the Finland Station. New York: New York Review, 2003.

WHITE, James. D. Lenin, Trotskii and the Arts of Insurrection: The Congress of Soviets of the Northern Region, 11-13 October 1917. In: WADE, Rex A. (Ed.). Revolutionary Russia: New Approaches. New York: Routledge, 2004.

ŽIŽEK, Slavoj. A visão em paralaxe. São Paulo: Boitempo, 2008a.

ŽIŽEK, Slavoj. Alguém disse totalitarismo? Cinco intervenções no (mau) uso de uma noção. São Paulo: Boitempo, 2013a.

ŽIŽEK, Slavoj. Às Portas da Revolução: Escritos de Lenin de 1917. São Paulo: Boitempo, 2005a.

ŽIŽEK, Slavoj. Como ler Lacan. Rio de Janeiro: Zahar, 2010.

ŽIŽEK, Slavoj. Em defesa das causas perdidas. São Paulo: Boitempo, 2011.

ŽIŽEK, Slavoj. Enjoy your sympton! Jacques Lacan in Hollywood and out. London: Routledge, Chapman and Hall, Inc., 1992. 
ŽIŽEK, Slavoj. Interrogating the Real. Bloomsbury, 2005 b.

ŽIŽEK, Slavoj. Menos que nada: Hegel à sombra do materialismo histórico. São Paulo: Boitempo, $2013 b$.

ŽIŽEK, Slavoj. O ano em que sonhamos perigosamente. São Paulo: Boitempo, 2012a.

ŽIŽEK, Slavoj. Órgãos sem corpos: Deleuze e consequências. Rio de Janeiro: Cia de Freud, 2008b.

ŽIŽEK, Slavoj. The Plague of Fantasies. London, Verso, 2008c.

ŽIŽEK, Slavoj. The Revolution must strike twice. London Review of Books, v. 24, n. 14, p. 13-15, July 25, 2002. Disponível em: < https://www.lrb.co.uk/v24/n14/slavoj-zizek/revolution-must-strike-twice >. Acesso em: 02 jun. 2017.

ŽIŽEK, Slavoj. Vivendo no fim dos tempos. São Paulo: Boitempo, 2012 b.

Data da submissão: 09 de fevereiro de 2018 Avaliado em: 25 de maio de 2018 (AVALIADOR A) Avaliado em: 14 de maio de 2018 (AVALIADOR B) Aceito em: 25 de junho de 2018 